\title{
DOCHODZENIE W SPRAWIE WYPADKU LOTNICZEGO Z ZASTOSOWANIEM DYNAMICZNEGO SYMULATORA LOTU
}

\author{
RAFAE LEWKOWICZ \\ Wojskowy Instytut Medycyny Lotniczej, Warszawa \\ e-mail: rlewkowicz@wiml.waw.pl
}

Celem prezentowanych badań była ocena przydatności dynamicznego symulatora lotu (wirówki przeciążeniowej HTC-07) do odtwarzania krytycznej fazy lotu samolotu F-16. Ocena przydatności symulatora polegała na porównaniu przyspieszenia liniowego oraz prędkości kątowej oddziałujących na pilota w locie rzeczywistym z przyspieszeniem oddziałujaccym na niego podczas odtwarzania tego lotu w symulatorze. Do oceny zgodności tych wielkości zastosowano pierwiastek błędu średniokwadratowego oraz współczynnik korelacji liniowej. Biorąc pod uwagę, że zaburzenia wzrokowe oraz utrata świadomości u pilota są wynikiem głównie składowej pionowej przyspieszenia liniowego, to niedostateczna zgodność w odtwarzaniu pozostałych składowych tego przyspieszenia oraz składowych prędkości kątowej nie dyskwalifikuje tego symulatora z możliwości jego zastosowania w badaniach przyczyn poważanych incydentów i wypadków lotniczych.

Stowa kluczowe: symulator lotu, wirówka przeciążeniowa, wypadek lotniczy, bezpieczeństwo lotu

\section{Spis zastosowanych skrótów i oznaczeń}

$\begin{array}{lll}G x_{G} y_{G} z_{G} & - & \text { układ współrzędnych związany z głową pilota } \\ O_{Z} x_{Z} y_{Z} z_{Z} & - & \text { nieruchomy układ współrzędnych związany z Ziemią (inercjalny) } \\ S x_{R} y_{R} z_{R} & - & \text { ruchomy układ współrzędnych związany z Ziemią } \\ S x_{S} y_{S} z_{S} & - & \text { układ współrzędnych związany z samolotem } \\ K x_{K} y_{K} z_{K} & - & \text { układ współrzędnych wiązany z kabiną symulatora } \\ \phi, \theta, \psi & - & \text { kąty opisujące orientacje przestrzenną w zakresie przechylenia, pochylenia } \\ & & \text { i odchylenia } \\ a_{x}, a_{y}, a_{z} & - & \text { składowe przyspieszenia liniowego } \\ p, q, r & - & \text { składowe prędkości kątowej (prędkość przechylania, pochylania i odchylania) } \\ \mathbf{b} & - & \text { wektor parametrów lotu rzeczywistego odtwarzanego w symulatorze } \\ \mathbf{k} & - & \text { wektor parametrów kinematyki kabiny symulatora } \\ \mathbf{I}_{G} & - & \text { wektor opisujący położenie środka układu Gx } x_{G} y_{G} z_{G} \text { związanego z głową } \\ & & \text { względem początku układu } S x_{S} y_{S} z_{S} \text { związanego z samolotem } \\ S & - & \text { w indeksie górnym lub dolnym reprezentuje dane związane z samolotem } \\ K & - & \text { w indeksie dolnym reprezentuje dane związane z kabiną symulatora } \\ G & - & \text { w indeksie dolnym reprezentuje dane związane z głową pilota } \\ h t c & - & \text { pierwiastek błędu średniokwadratowego }\end{array}$

\section{Wstęp}

Jednym z ważniejszych zadań w badaniu przyczyny poważnego incydentu lub wypadku lotniczego jest próba odtworzenia i zrozumienia zachowania pilota w krytycznej fazie lotu. Podstawowym problemem, przed którym stają członkowie komisji jest zebranie jak największej ilości 
informacji dotyczących nie tylko sposobu pracy poszczególnych podzespołów statku powietrznego, lecz również zachowania się pilota w końcowej fazie lotu.

W celu rekonstrukcji lotu gromadzone są dane z różnych źródeł, m.in. rejestratora danych lotu, rejestratora głosu w kokpicie czy też zeznania naocznych świadków. Pomimo że są to dane często kluczowe w wyjaśnianiu sekwencji zdarzeń prowadzących do wypadku, to nie zawsze umożliwiają udzielenie odpowiedzi na pytanie dotyczące przyczyn działania pilota. Dopiero dokładna analiza lotu oraz warunków, w jakich się on odbywał, może pozwolić na ocenę zachowanie załogi i określić przyczynę błędnego działania pilota.

W trakcie badań w locie rzeczywistym odtworzenie warunków oraz sekwencji działania załogi podczas krytycznej fazy lotu związane jest zwykle z wysokim niebezpieczeństwem i znacznymi kosztami takich ekspertyz. Z tego względu podczas dochodzenia w sprawie wypadku lotniczego kluczową rolę w badaniach jego przyczyn odgrywa symulacja, na potrzeby której wykorzystywane są modele bądź urządzenia odwzorowujące wybrane scenariusze lotu.

\subsection{Zastosowanie symulatorów $\mathrm{w}$ badaniach przyczyn wypadków lotniczych}

W celu przeanalizowania zachowania pilota oraz czynników, które oddziaływały na niego w czasie lotu, badacze wypadków gromadzą różnorodne dane. Odtworzenie w symulatorze lotu wybranych warunków z krytycznej fazy lotu odbywa się głównie w oparciu o dane z rejestratora danych lotu [1]. W przypadku braku tych danych, odtworzenie lotu, chociaż mniej dokładne, może odbywać się na podstawie zarejestrowanego obrazu (z widokiem wyświetlacza przeziernego, wielofunkcyjnego lub obrazu z wyświetlacza hełmowego pilota), danych z radaru bądź też zeznań naocznych świadków.

Podczas gdy większość symulatorów lotu ma funkcję, która umożliwia odtwarzanie danych w symulatorze w celach szkoleniowych, niewiele jest tego typu urządzeń, które zostały zaprojektowane do przyjmowania i odtwarzania danych z rejestratora danych lotu [2]. Ponadto ze względu na występujące ograniczenia, m.in. niewielką liczbę stopni swobody układu ruchu oraz niską rozdzielczość i zakres pola zobrazowania scenerii lotu, nie zawsze urządzenia te umożliwiają odtworzenie rzeczywistego lotu z wysoką wiernością. Należy również podkreślić, że wiarygodność takich symulacji zależy głównie od tego, czy są one oparte na danych, które zostały skrupulatnie zmierzone i zarejestrowane w czasie rzeczywistego lotu.

Chociaż odtworzenie w symulatorze skojarzonego oddziaływania na pilota kilku fizycznych czynników środowiska rzeczywistego lotu, np. przyspieszeń, niskiego ciśnienia i niedotlenienia, może być trudnym zadaniem, to odwzorowanie jedynie przyspieszeń liniowych nie powinno stanowić problemu. Przyspieszenia, oddziałujące na pilota głównie w locie samolotem odrzutowym, stanowią bowiem istotny problem z punktu widzenia bezpieczeństwa lotów. Ich skutkiem może być nie tylko przeciążeniowa utrata świadomości ( $G$-induced Loss of Consciousness, G-LOC), lecz również zaburzenia wzrokowe, które są niekiedy symptomem zbliżającego się G-LOC. Występowanie tych zaburzeń stanowi również potencjalne niebezpieczeństwo utraty orientacji przestrzennej, której skutkiem może być utrata kontroli w locie lub tzw. kontrolowany lot ku ziemi.

\subsection{Zaburzenia wzrokowe podczas oddziaływania przyspieszeń}

Główną przyczyną występowania zaburzeń wzrokowych podczas lotu są przyspieszenia dośrodkowe, które generują siły bezwładności działające na pilota w kierunku głowa-nogi (przyspieszenie to opisuje się symbolem $+G_{z}$ ). Na skutek działania tych sił dochodzi do przemieszczenia krwi z obszaru głowy w kierunku kończyn dolnych, a w następstwie niedotlenienie ośrodkowego układu nerwowego (OUN). Występujący w tych warunkach spadek ciśnienia krwi na poziomie głowy jest przyczyną zmniejszenia przepływu krwi w naczyniach siatkówki oka i pojawienia się zaburzeń wzrokowych [3]. 
Moment wystąpienia i stopień zaburzeń wzrokowych uzależniony jest między innymi od prędkości narastania przyspieszenia, jego wartości i czasu trwania, a także od poprawności wykonywanych przez pilota manewrów przeciwprzeciążeniowych (Anti-G Straining Maneuver, AGSM) tzw. manewru L-1 (manewr polega na napięciu mięśni kończyn dolnych z jednoczesnym wykonywania manewru Valsalvy).

Zaburzenia widzenia rozpoczynają się zwykle od utraty obwodowego widzenia (tzw. widzenie tunelowe) oraz pojawienia się przed oczami zamglenia, które utrudnia zdolność rozpoznawania obiektów. Działanie przyspieszenia $+G_{z}$ doprowadza również do zmiany kształtu gałek ocznych na skutek ich naporu na dolne ściany oczodołów. Dochodzi w tych warunkach do krótkowzroczności osiowej, wzrastającej stopniowo począwszy od wartości przyspieszenia $+3 G_{z}$ [3]. W miarę narastania przyspieszenia zaburzenia wzrokowe nasilają się i pogłębiają. Niekiedy występuje utrata widzenia barwnego, a w niektórych przypadkach piloci doznaja całkowitej utraty widzenia, tzw. „black-out”. Dalsze działanie przyspieszenia doprowadza do G-LOC. Podczas działania przyspieszeń w przeciwnym kierunku (nogi-głowa) zaburzenia wzrokowe mają inny charakter. Objawiają się one zwykle poczerwienieniem, a niekiedy pożółceniem pola widzenia [3].

Wielu autorów [3], [4] wskazuje niekorzystny wpływ przyspieszeń w locie nie tylko z niedotlenieniem siatkówki (zaburzeniami wzrokowymi), lecz również z zaburzeniami czynnościowymi OUN. Skutkiem tych zaburzeń są: wydłużenie czasu reakcji na bodziec świetlny [5], [6], podwyższenie progu percepcji barw [7]-[9] oraz zmiana percepcji krytycznej częstotliwości zlewania się bodźca świetlnego [10], [11].

\subsection{Cel badań}

Analizując przyczynę wypadku lotniczego, który poprzedzony był lotem z wysokimi i długotrwałymi przyspieszeniami liniowymi, można przypuszczać, że zaburzenia widzenia lub GLOC mogły być następstwem obniżonej tolerancji przyspieszeń bądź nieprawidłowo wykonanego AGSM. Jednym z możliwych sposobów weryfikacji tych założeń i wskazania przyczyny błędu pilota jest zastosowanie dynamicznego symulatora lotu, którego konstrukcja oparta na wirówce przeciążeniowej umożliwia odtworzenie wysokich, szybko narastających i długotrwałych przeciążeń.

Celem prezentowanych badań była ocena przydatność wirówki przeciążeniowej jako dynamicznego symulatora lotu do odtwarzania przyspieszeń charakterystycznych dla lotu samolotu odrzutowego. Zamiarem autora było również wykazanie możliwych korzyści z zastosowania tego symulatora w dochodzeniu przyczyn wypadku lub poważnego incydentu lotniczego.

Ocenę przydatności symulatora oparto na zgodności składowych przyspieszenia liniowego oraz prędkości kątowej oddziałujących na pilota w locie rzeczywistym z odpowiadającymi im wielkościami generowanymi przez symulator podczas odtwarzania tego lotu. Zakłada się, że proponowany sposób dochodzenia przyczyn wypadku lotniczego pozwoli osobom zajmujących się tym problemem spojrzeć na dane z lotu z innej perspektywy i ustalić, czy występujące w locie przyspieszenie mogło przyczynić się do wystąpienia zaburzeń wzrokowych u pilota.

\section{Metoda badań}

\subsection{Symulator lotu}

Do odtworzenia lotu rzeczywistego wykorzystano dynamiczny symulator lotu HTC-07 (Human Training Centrifuge, HTC) (AMST-Systemtechnik GmbH, Austria) (rys. 1), zlokalizowany w Wojskowym Instytucie Medycyny Lotniczej. Urządzenie to łączy w sobie funkcje symulatora lotu i wirówki przeciążeniowej, poprzez co wykorzystywane jest zarówno do treningu lotniczego pilotów, jak i oceny predyspozycji pilota do tolerancji wysokich i długotrwałych przeciążeń. 


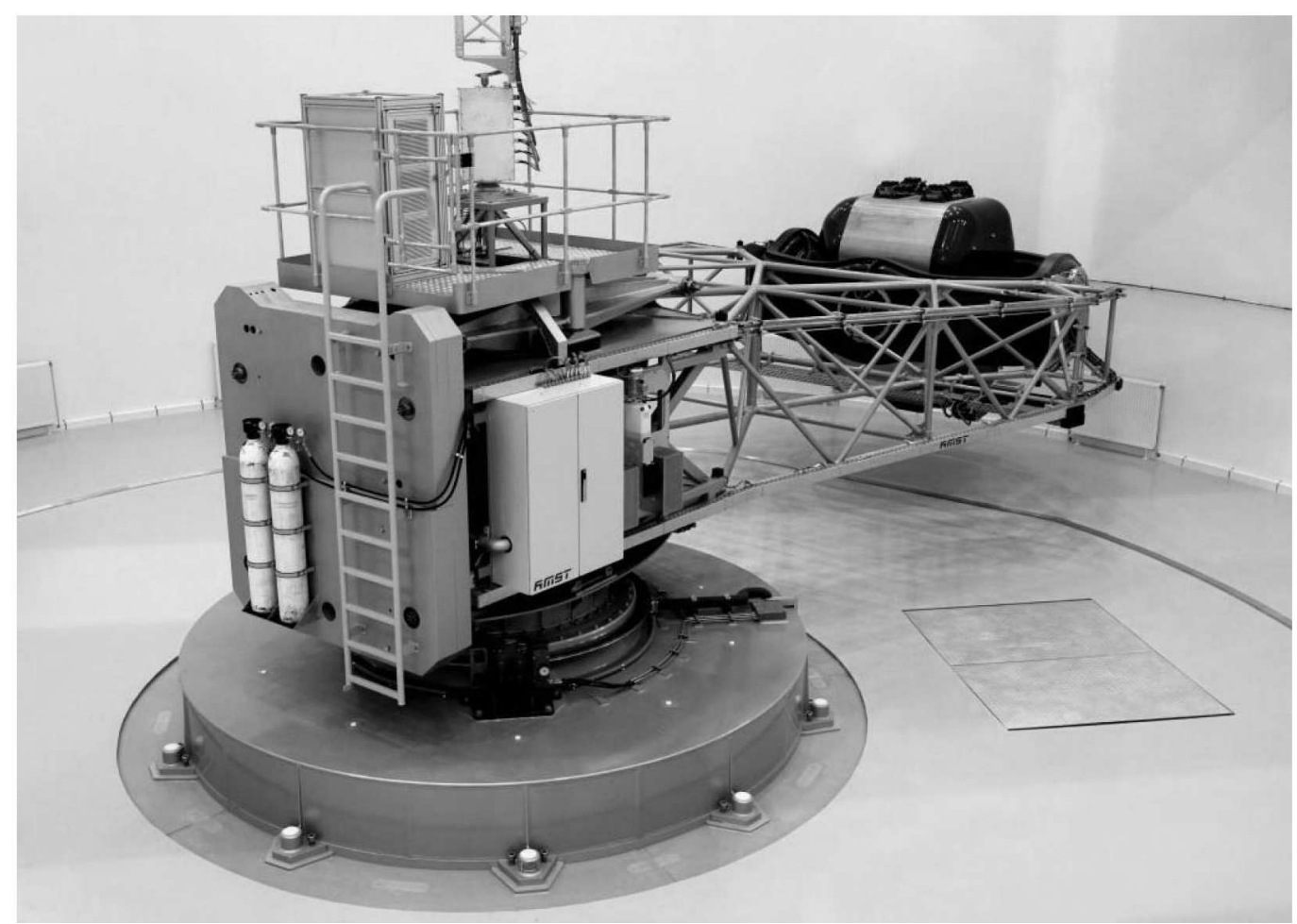

Rys. 1. Dynamiczny symulator lotu - wirówka przeciążeniowa HTC-07

Układ ruchu symulatora o 3 stopniach swobody oraz kabiną zawieszoną żyroskopowo na 8metrowym ramieniu umożliwia generowanie przyspieszenia jednocześnie w trzech osiach. Zakres wytwarzanego przyspieszenia oraz graniczne parametry kinematyki części roboczej symulatora przedstawiono w tabeli 1.

Tabela 1. Graniczne parametry kinematyki układu ruchu symulatora HTC-07 [12]

\begin{tabular}{|c|c|c|c|}
\hline Parametr & Oś $K x_{K}^{*}$ & Oś $K y_{K}^{*}$ & Oś $K z_{K}^{*}$ \\
\hline Z Zakres ruchu względem osi $\left[^{\circ}\right]$ & - & \pm 360 & \pm 360 \\
\hline Maksymalne przyspieszenie [G] & $16 /-3$ & \pm 6 & \pm 10 \\
\hline Maksymalny przyrost przyspieszenia $[\mathrm{G} / \mathrm{s}]$ & 14,5 & 6 & 10 \\
\hline Maksymalne przyspieszenie kątowe $\left[\mathrm{rad} / \mathrm{s}^{2}\right]$ & 2,82 & 8 & 5 \\
\hline
\end{tabular}

Kabina wirówki ma możliwość odwzorowania wyposażenia kokpitów samolotów F-16 Block 52+ oraz MiG-29. Opcja ta zapewnia pilotowi wykonanie czynności, które można obecnie realizować na tradycyjnym symulatorze lotu, m.in. czynności przedstartowe, loty wg przyrządów oraz nawigowanie i podejścia do lądowania według VOR, VOR/DME, NDB, ILS oraz TACAN, obsługę urządzeń łączności, procedury lotów w warunkach nocnych, loty grupowe i nawigację w trudnych warunkach pogodowych. Symulator ten umożliwia ponadto prowadzenie treningów $\mathrm{w}$ zakresie wyprowadzania statku powietrznego z nietypowych położeń, sytuacji awaryjnych (pożar silnika, uszkodzenie systemu sterowania) oraz zastosowania bojowego (przechwytywanie celów powietrznych, manewrów obronnych, użycia uzbrojenia) [13].

Producent wirówki przeciążeniowej HTC-07 dostarczył możliwość odtwarzania w symulatorze dowolnych scenariuszy lotu samolotów MiG-29 oraz F-16, jednakże w dokumentacji urządzenia 
nie zamieścił danych, które potwierdzają dokładności tego odtwarzania. W instrukcji użytkowania symulatora HTC-07 [12] zdefiniowano 10 parametrów (tabela 2), które stanowią minimalny zestaw danych wymaganych do odtworzenia lotu w symulatorze. Dane te rozdzielone są średnikiem i zapisane w formacie ASCII (American Standard Code for Information Interchange).

Tabela 2. Minimalny zestaw danych wymaganych do odtworzenia lotu w symulatorze HTC-07

\begin{tabular}{|c|c|c|c|c|c|}
\hline \multicolumn{2}{|c|}{ Parametr } & JM & Zakres & $\begin{array}{c}\text { Typ } \\
\text { danych }\end{array}$ & $\begin{array}{c}\text { Oznaczenie w pliku } \\
\text { źródłowym }\end{array}$ \\
\hline \multicolumn{2}{|c|}{ 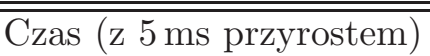 } & $\mathrm{ms}$ & - & double & Header.Timestamp \\
\hline \multirow{3}{*}{$\begin{array}{l}\text { Składowe } \\
\text { przyspieszenia } \\
\text { liniowego }\end{array}$} & $a_{x_{K}}^{h t c}$ & \multirow{3}{*}{$\mathrm{m} / \mathrm{s}^{2}$} & \pm 6 & float & MSIout.Motion.f_x_b* \\
\hline & $a_{y_{K}}^{\text {htc }}$ & & \pm 10 & float & MSIout.Motion.f_y_b* \\
\hline & $a_{z_{K}}^{\text {htc }}$ & & $\langle-6 ;+16\rangle$ & float & MSIout.Motion.f_z_b* \\
\hline \multicolumn{2}{|l|}{ Wysokość } & $\mathrm{m}$ & - & float & MSIout.OTW.h_eye \\
\hline \multicolumn{2}{|c|}{ Szerokość geograficzna } & $\begin{array}{l}\text { stopnie, } \\
\text { minuty }\end{array}$ & $\langle-90 ; 90\rangle$ & double & MSIout.OTW.Lat_eye \\
\hline \multicolumn{2}{|c|}{ Długość geograficzna } & $\begin{array}{c}\text { sekundy } \\
\text { kątowe }\end{array}$ & $\langle-180 ; 180\rangle$ & double & MSIout.OTW.Lon_eye \\
\hline \multicolumn{2}{|l|}{ Pora dnia } & $\mathrm{h}$ & $\langle 0 ; 24\rangle$ & $\langle 0 ; 24\rangle$ & MSIout.OTW.ToD \\
\hline \multicolumn{2}{|c|}{ Kąt przechylenia } & \multirow{3}{*}{$\mathrm{rad}$} & $\pm \pi$ & float & MSIout.OTW.phi \\
\hline \multirow{2}{*}{\multicolumn{2}{|c|}{$\begin{array}{l}\text { Kąt pochylenia } \\
\text { Kat odchylenia }\end{array}$}} & & $\pm \pi / 2$ & float & MSIout.OTW.theta \\
\hline & & & $\pm \pi$ & float & MSIout.OTW.psi \\
\hline
\end{tabular}

* - w układzie $K x_{K} y_{K} z_{K}$ związanym z kabiną symulatora

(układ zdefiniowany w Dodatku A)

W celu dodatkowego zobrazowania wskazań przyrządów pokładowych, np. prędkościomierza, niezbędne jest uzupełnienie danych zawartych w tabeli 2 o dane na temat prędkości lotu. Na potrzeby prezentowanych badań do odtworzenia lotu rzeczywistego w symulatorze HTC-07 wybrano zestaw parametrów przedstawionych w tabeli 2. Parametry te tworzą wektor, który zapewnia zarówno generowanie fizycznych przyspieszeń liniowych, jak i zobrazowania scenerii lotu.

\subsection{Dane $\mathrm{z}$ rejestratora danych lotu}

Do odtworzenia w dynamicznym symulatorze lotu HTC-07 wybrano 20-sekundowy fragment lotu rzeczywistego samolotu F-16, zarejestrowany w pamięci rejestratora katastroficznego (Enhanced Crash Survivable Memory Unit, ECSMU). Przyjęty do analizy plik danych zawierał 253 parametry, spośród których do utworzenia wektora b odtwarzanego w symulatorze HTC-07 wybrano 12 parametrów przedstawionych w tabeli 3. Wektor $\mathbf{b}$ parametrów lotu rzeczywistego odtwarzanego w symulatorze HTC-07 (tabela 3) ma następującą postać w układzie współrzędnych $G x_{G} y_{G} z_{G}$ związanym z głową pilota

$$
\mathbf{b}=\left[\phi_{G / Z}, \theta_{G / Z}, \psi_{G / Z}, a_{x_{G}}^{s}, a_{y_{G}}^{s}, a_{z_{G}}^{s}, p_{x_{G}}^{s}, q_{y_{G}}^{s}, r_{z_{G}}^{s}, x_{x_{Z}}, x_{y_{Z}}, x_{z_{Z}}\right]^{\mathrm{T}}
$$

Na rys. 2 przedstawiono analizowany w tej pracy fragment zapisu rejestratora katastroficznego ECSMU. Przyjęta do analizy 20-sekundowa faza lotu obejmowała manewr zakrętu w prawo z przeciążeniem do $+5 G_{z}$ (przeciążenie oddziałujące wzdłuż osi podłużnej ciała pilota, o zwrocie do kończyn dolnych) zakończony manewrem beczki. Przyspieszenia oraz prędkości kątowe, jakkolwiek obarczone błędami pomiaru i przetwarzania [14], [15], przyjęto za wystarczające pod względem dokładności do odtworzenia lotu w symulatorze HTC-07. 
Tabela 3. Wybrane parametry lotu zapisane w pamięci rejestratora katastroficznego ECSMU

\begin{tabular}{|c|c|c|c|c|c|c|}
\hline \multicolumn{2}{|c|}{ Parametr } & JM & \begin{tabular}{|c|} 
Częstotl. \\
zapisu $[\mathrm{Hz}]$
\end{tabular} & \begin{tabular}{c|} 
Układ \\
odniesienia
\end{tabular} & \begin{tabular}{|c|} 
Skład. \\
wektora b
\end{tabular} & $\begin{array}{c}\text { Oznacz. w pliku } \\
\text { źródłowym }\end{array}$ \\
\hline \multirow{3}{*}{ Kąt } & \multirow{3}{*}{$\begin{array}{c}\text { przechylenia } \phi_{S} \\
\text { pochylenia } \theta_{S} \\
\text { odchylenia } \psi_{S}\end{array}$} & \multirow{3}{*}{$\begin{array}{l}\text { stopnie } \\
\text { kątowe }\end{array}$} & \multirow{3}{*}{4} & \multirow{3}{*}{\begin{tabular}{|c|}
$O_{Z} x_{Z} y_{Z} z_{Z}$ \\
związany \\
z ziemią** $^{* *}$
\end{tabular}} & 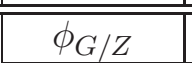 & 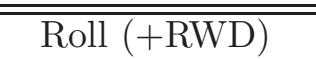 \\
\hline & & & & & $\theta_{G / Z}$ & Pitch (+NU) \\
\hline & & & & & $\psi_{G / Z}$ & TrueHead \\
\hline \multirow{3}{*}{$\begin{array}{l}\text { Przysp. } \\
\text { liniowe } \\
\mathbf{a}_{S}{ }^{* * *}\end{array}$} & $a_{x_{S}}$ & \multirow{3}{*}{ g } & 4 & \multirow{6}{*}{$\begin{array}{c}S x_{S} y_{S} z_{S} \\
\text { związany } \\
\text { z samo- } \\
\text { lotem** }\end{array}$} & \multirow{3}{*}{$\mathbf{a}_{G}^{S *}$} & LongAcc \\
\hline & $a_{y_{S}}$ & & 8 & & & LatAcc \\
\hline & $a_{z_{S}}$ & & 8 & & & NormG_Nz \\
\hline \multirow{3}{*}{$\begin{array}{l}\text { Prędkość } \\
\text { kątowa } \Omega_{S}\end{array}$} & przechylania $p_{S}$ & \multirow{3}{*}{$\mathrm{deg} / \mathrm{s}$} & \multirow{3}{*}{4} & & \multirow{3}{*}{$\Omega_{G}^{s}$} & RollRate (+RWD) \\
\hline & pochylania $q_{S}$ & & & & & PitchRate $(+\mathrm{NU})$ \\
\hline & odchylania $r_{S}$ & & & & & YawRate $(+\mathrm{NR})$ \\
\hline $\begin{array}{l}\text { Wysokość } \\
\text { lotu }\end{array}$ & $h_{z_{Z}}$ & stopy & 1 & \begin{tabular}{|c|}
$O_{Z} x_{Z} y_{Z} z_{Z}$ \\
związany \\
z Ziemią**
\end{tabular} & \multirow{3}{*}{$\mathbf{x}_{Z}$} & BaroAlt \\
\hline \begin{tabular}{l|} 
Długość \\
geograficzna
\end{tabular} & $\lambda_{g e o}$ & \multirow{2}{*}{$\begin{array}{c}\text { stopnie, } \\
\text { minuty, } \\
\text { sek. } \\
\text { katowe }\end{array}$} & \multirow{2}{*}{1} & \multirow{2}{*}{$\begin{array}{l}\text { układ } \\
\text { współ. } \\
\text { geograf. }\end{array}$} & & Nav_Long \\
\hline \begin{tabular}{|l|} 
Szerokość \\
geograficzna
\end{tabular} & $\varphi_{g e o}$ & & & & & Nav_Lat \\
\hline
\end{tabular}

* - po transformacji do układu $G x_{G} y_{G} z_{G}$ związanego z głowa pilota

(układ zdefiniowany w rozdz. 2.3)

** - układ zdefiniowany w rozdz. 2.3

*** - bez komponentu przyspieszenia grawitacyjnego
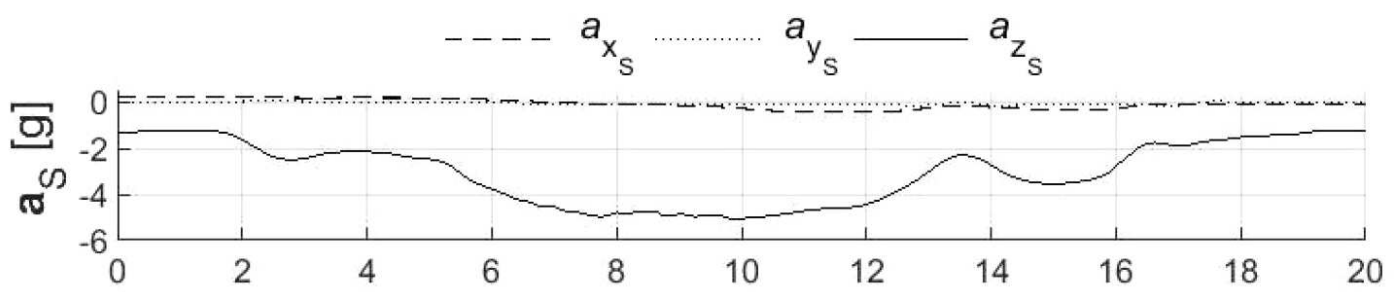

$$
---p_{\mathrm{S}} \cdots \cdots \cdots \cdots q_{\mathrm{S}}-r_{\mathrm{S}}
$$
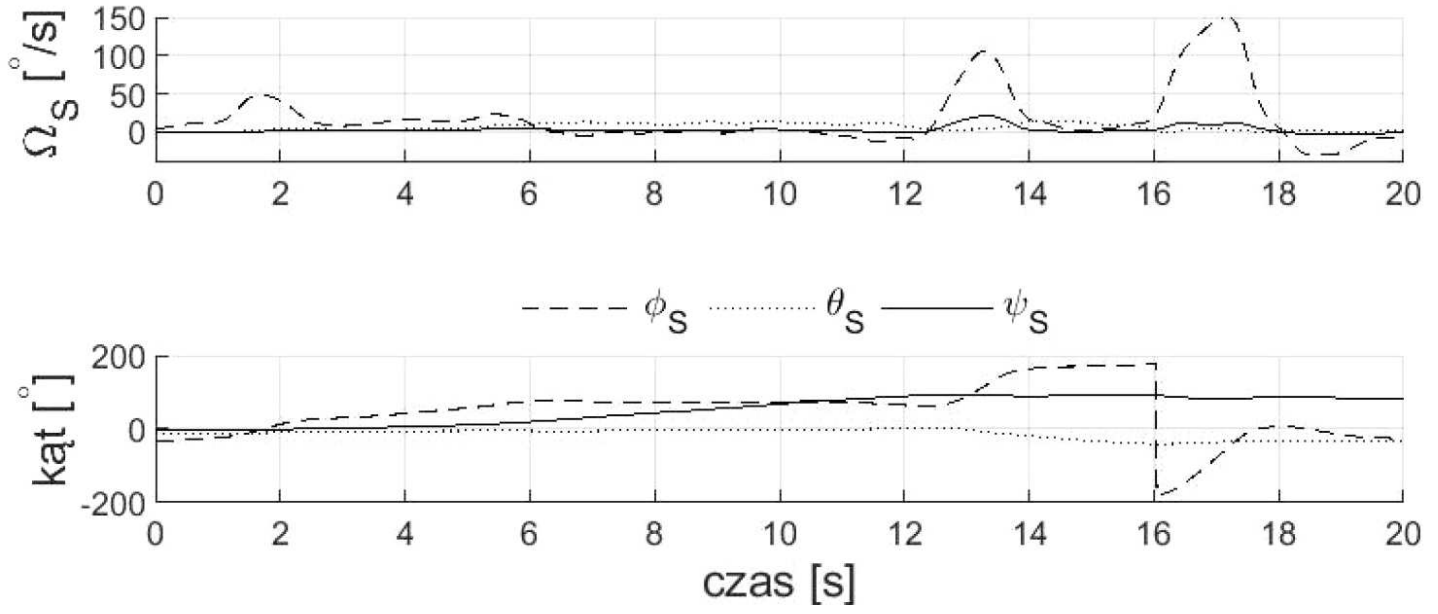

Rys. 2. Analizowany fragment zapisu rejestratora ECSMU 


\subsection{Procedura odtworzenia lotu rzeczywistego}

Odtworzenie lotu rzeczywistego samolotu F-16 w symulatorze HTC-07 podzielono na trzy fazy:

I - obejmujacca przygotowanie i dostosowanie danych z rejestratora danych lotu ECSMU do odtworzenia w symulatorze,

II - polegająca na odtworzeniu w symulatorze zarejestrowanego scenariusza lotu samolotu F-16 oraz

III - dotycząca porównania przyspieszeń, których pilot doświadczył w locie rzeczywistym z przyspieszeniami zarejestrowanymi podczas odtwarzania tego lotu w symulatorze.

\section{Faza I - przygotowanie danych z lotu}

Przyspieszenie liniowe odtwarzane w symulatorze HTC-07 opisane jest w układzie związanym z głowa pilota (tabela 1), a przyspieszenie zarejestrowane w locie rzeczywistym opisane jest w układzie związanym z samolotem (tabela 2), dlatego konieczne jest przekształcenie danych z lotu do układu związanego z głową pilota. Do opisu przyspieszeń liniowych i prędkości kątowych oddziałujących na głowę pilota w samolocie wykorzystano niżej zdefiniowane prostokątne, prawoskrętne układy współrzędnych (rys. 3):

- Nieruchomy układ współrzędnych związany z Ziemią (inercjalny) $-O_{Z} x_{Z} y_{Z} z_{Z}$. Początkiem tego układu jest dowolnie wybrany punkt $O_{Z}$ na powierzchni Ziemi. Oś $O_{Z} x_{Z}$ ma kierunek wzdłuż początkowego kierunku lotu samolotu oraz leży w płaszczyźnie $O_{Z} x_{Z} y_{Z}$ powierzchni Ziemi. Składowe wektorów w tym układzie oznaczono indeksem dolnym $Z$.

- Ruchomy układ współrzędnych związany z Ziemią $-S x_{R} y_{R} z_{R}$. Grawitacyjny układ ziemski o początku w środku masy samolotu. Ośs $S z_{R}$ skierowana jest zgodnie z wektorem siły ciężkości o zwrocie do środka Ziemi. Osie $S x_{R}$ i $S y_{R}$ leżą w płaszczyźnie horyzontu, przy czym oś $S x_{R}$ pokrywa się z linią początkowego kursu samolotu. Składowe wektorów w tym układzie współrzędnych wyróżniono indeksem dolnym $R$.

- Układ współrzędnych związany z samolotem - Sx $x_{S} y_{S}$. Początek układu przyjmuje się w środku masy samolotu. Oś podłużna $S x_{S}$ stanowi główną oś bezwładności i ma zwrot w kierunku nosa samolotu oraz leży w płaszczyźnie $S x_{S} z_{S}$ symetrii geometrycznej, masowej i aerodynamicznej samolotu. Składowe wektorów wyrażane w układzie współrzędnych związanym z samolotem wyróżniono indeksem dolnym $S$.

- Układ współrzędnych związany z głową pilota - $G x_{G} y_{G} z_{G}$. Układu o początku w środku głowy i osi podłużnej $G x_{G}$ położonej na płaszczyźnie Reida [16] i skierowanej do przodu zgodnie z kierunkiem patrzenia. Ośs pionowa $G z_{G}$ ma zwrot w dół głowy, natomiast oś poprzeczna $G y_{G}$ skierowana jest w stronę prawego ucha. Składowe wektorów wyrażane w układzie współrzędnych związanym z głową wyróżniono indeksem dolnym $G$.

Kierunki i zwroty poszczególnych osi układów współrzędnych oznaczono na rys. 3.

Położenie początku układu $G x_{G} y_{G} z_{G}$ związanego z głową względem początku układu $S x_{S} y_{S} z_{S}$, określa wektor $\mathbf{I}_{G}$ (rys. 3). Wektor ten ma w układzie $S x_{S} y_{S} z_{S}$ dwie składowe niezerowe $\mathbf{I}_{G}=\left[l_{G x_{S}}, 0, l_{G z_{S}}\right]^{\mathrm{T}}$. Przyjęto, że odległość głowy pilota (początku układu $G x_{G} y_{G} z_{G}$ ) od osi $S x_{S}$ układu $S x_{S} y_{S} z_{S}$ związanego z samolotem wynosi $l_{G z_{S}}=1,0 \mathrm{~m}$, natomiast odległość środka układu $S x_{S} y_{S} z_{S}$ (środka masy) od rzutu początku układu $G x_{G} y_{G} z_{G}$ na oś $S x_{S}$ równa jest $l_{G x_{S}}=4,15 \mathrm{~m}$ (rys. 3 ). W związku z tym podczas obrotu samolotu mogą dodatkowo wystąpić doosiowe i styczne składowe przyspieszenia liniowego oddziałujaccego na głowę pilota. Przyspieszenie wypadkowe jest zatem sumą trzech przyspieszeń

$$
\mathbf{a}_{G}^{s}=\mathbf{a}_{S}+\mathbf{a}_{\epsilon}+\mathbf{a}_{\Omega}
$$




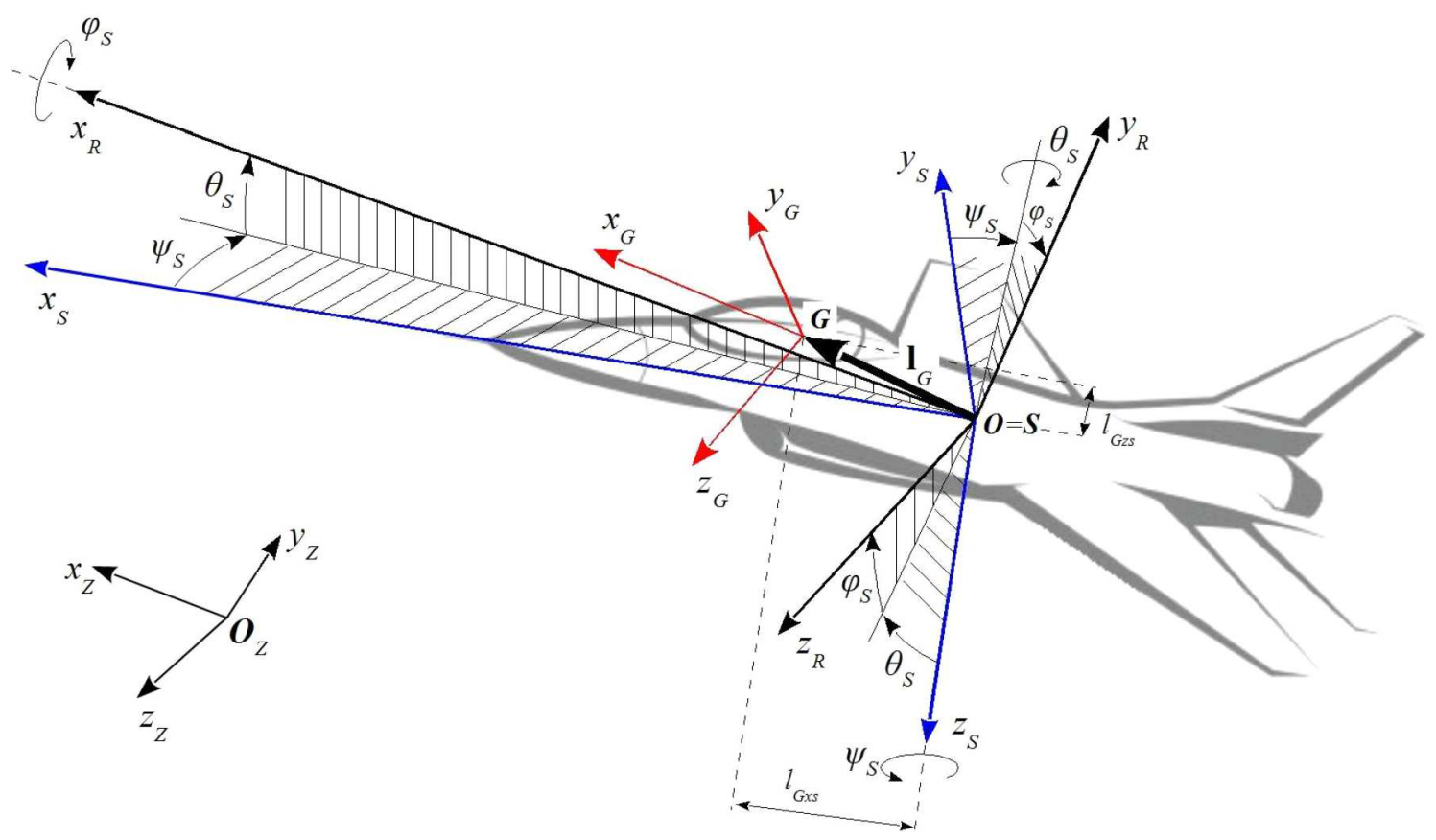

Rys. 3. Zdefiniowane układy współrzędnych oraz kąty przejścia pomiędzy nimi

gdzie:

$\mathbf{a}_{S}=\left[a_{x_{S}}, a_{y_{S}}, a_{z_{S}}\right]^{\mathrm{T}}-$ przyspieszenie bezwzględne środka masy samolotu, zarejestrowane w pamięci rejestratora katastroficznego ECSMU (tabela 2);

$\mathbf{a}_{\epsilon}=\boldsymbol{\epsilon}_{S} \times \mathbf{I}_{G}-$ przyspieszenie styczne, którego składowe są następujące

$$
\begin{aligned}
& a_{\epsilon x_{S}}=\dot{q}_{S} l_{G z_{S}}-\dot{r}_{S} l_{G y_{S}} \\
& a_{\epsilon y_{S}}=\dot{r}_{S} l_{G x_{S}}-\dot{p}_{S} l_{G z_{S}} \\
& a_{\epsilon z_{S}}=\dot{p}_{S} l_{G y_{S}}-\dot{q}_{S} l_{G x_{S}}
\end{aligned}
$$

$\mathbf{a}_{\Omega}=\boldsymbol{\Omega}_{S} \times\left(\boldsymbol{\Omega}_{S} \times \mathbf{I}_{G}\right)-$ przyspieszenie doosiowr o składowych

$$
\begin{aligned}
& a_{x_{S}}=p_{S}\left(p_{S} l_{G x_{S}}+q_{S} l_{G y_{S}}+r_{S} l_{G z_{S}}\right)-\Omega_{S}^{2} l_{G x_{S}} \\
& a_{x_{S}}=q_{S}\left(p_{S} l_{G x_{S}}+q_{S} l_{G y_{S}}+r_{S} l_{G z_{S}}\right)-\Omega_{S}^{2} l_{G y_{S}} \\
& a_{x_{S}}=r_{S}\left(p_{S} l_{G x_{S}}+q_{S} l_{G y_{S}}+r_{S} l_{G z_{S}}\right)-\Omega_{S}^{2} l_{G z_{S}}
\end{aligned}
$$

Zatem przyspieszenie $\mathbf{a}_{G^{s}}$ (2.1) oddziałujące na głowę pilota ma w układzie $G x_{G} y_{G} z_{G}$ następujące składowe

$$
\begin{aligned}
& a_{x_{G}}^{s}=a_{x_{S}}+\dot{q}_{S} l_{G z_{S}}-\dot{r}_{S} l_{G y_{S}}+p_{S}\left(p_{S} l_{G x_{S}}+q_{S} l_{G y_{S}}+r_{S} l_{G z_{S}}\right)-\Omega_{S}^{2} l_{G x_{S}} \\
& a_{y_{G}}^{s}=a_{y_{S}}+\dot{r}_{S} l_{G x_{S}}-\dot{p}_{S} l_{G z_{S}}+q_{S}\left(p_{S} l_{G x_{S}}+q_{S} l_{G y_{S}}+r_{S} l_{G z_{S}}\right)-\Omega_{S}^{2} l_{G y_{S}} \\
& a_{z_{G}}^{s}=a_{z_{S}}+\dot{p}_{S} l_{G y_{S}}-\dot{q}_{S} l_{G x_{S}}+r_{S}\left(p_{S} l_{G x_{S}}+q_{S} l_{G y_{S}}+r_{S} l_{G z_{S}}\right)-\Omega_{S}^{2} l_{G z_{S}}
\end{aligned}
$$

Zakładając, że podczas lotu nie występowała zmiana położenia kątowego głowy pilota względem samolotu, zachodzą następujące równości: $\phi_{G / Z}=\phi_{S}, \theta_{G / Z}=\theta_{S}, \psi_{G / Z}=\psi_{S}$ oraz $\boldsymbol{\Omega}_{G}^{s}=\boldsymbol{\Omega}_{S}$ (tabela 3 ). W rezultacie wektor $\mathbf{b}$ parametrów lotu rzeczywistego odtwarzanego w symulatorze HTC-07 (tabela 3) ma następując postać w układzie współrzędnych $G x_{G} y_{G} z_{G}$ związanym z głową pilota

$$
\mathbf{b}=\left[\phi_{S}, \theta_{S}, \psi_{S}, a_{x_{G}}^{s}, a_{y_{G}}^{s}, a_{z_{G}}^{s}, p_{S}, q_{S}, r_{S}, \varphi_{g e o}, \lambda_{g e o}, h_{z_{Z}}\right]^{\mathrm{T}}
$$


Z uwagi na to, że zapis danych $\mathrm{w}$ rejestratorze ECSMU odbywał się z różną częstotliwością (tabela 3, zależnie od typu danych od 1 do $8 \mathrm{~Hz}$ ) oraz częstotliwością mniejszą od wymaganej do odtworzenia w symulatorze HTC-07 (tabela 2, częstotliwość $200 \mathrm{~Hz}$ ), przeprowadzono interpolację tych danych za pomoca funkcji sklejanych trzeciego stopnia. Ponadto przeprowadzono przekształcenia jednostek miar, zgodnie $\mathrm{z}$ wykazem danych zamieszczonych $\mathrm{w}$ tabeli 2. Wykaz tych przekształceń przedstawiono w tabeli 4.

Tabela 4. Wykaz przekształceń jednostek miar danych z lotu rzeczywistego

\begin{tabular}{|c|c|c|c|c|}
\hline \multirow{2}{*}{\multicolumn{2}{|c|}{ Parametr }} & \multicolumn{3}{|c|}{ Oznaczenie parametru w pliku źródłowym } \\
\hline & & \multirow{2}{*}{$\frac{\text { F-16 }}{\overline{\text { LongAcc }}}$} & $\begin{array}{c}\text { Rodzaj } \\
\text { przekształcenia } \\
\end{array}$ & \multirow{2}{*}{$\frac{\text { HTC-07 }}{\text { MSIout.Motion.f_x_b }}$} \\
\hline \multirow{3}{*}{$\begin{array}{l}\text { Przyspieszenie } \\
\text { liniowe }\end{array}$} & $\overline{a_{x_{K}}^{h t c}}$ & & \multirow{3}{*}{$\mathrm{g}$ na m/s $\mathrm{s}^{2}$} & \\
\hline & $\begin{array}{l}a_{y_{K}}^{\text {htc }} \\
\end{array}$ & LatAcc & & MSIout.Motion.f_y_b \\
\hline & $a_{z_{K}}^{\frac{g k}{h t c}}$ & NormG_Nz & & MSIout.Motion.f_z_b \\
\hline \multicolumn{2}{|l|}{ Wysokość } & BaroAlt & stopy na metry & MSIout.OTW.h_eye \\
\hline \multicolumn{2}{|c|}{ Kąt przechylenia } & Roll (+RWD) & \multirow{3}{*}{$\begin{array}{c}\text { stopnie } \\
\text { kątowe na } \\
\text { radiany }\end{array}$} & MSIout.OTW.phi \\
\hline \multicolumn{2}{|l|}{ Kąt pochylenia } & Pitch $(+\mathrm{NU})$ & & MSIout.OTW.theta \\
\hline \multicolumn{2}{|l|}{ Kąt odchylenia } & TrueHead & & MSIout.OTW.psi \\
\hline
\end{tabular}

Utworzony w ten sposób wektor $\mathbf{b}$ parametrów lotu odtwarzanych w symulatorze zapisano do pliku ASCII. Plik ten poddano następnie weryfikacji pod względem poprawności formatu danych i zakresu ich wartości tak, aby uniemożliwić przekroczenie granicznych, dopuszczalnych przez producenta symulatora HTC-07 parametrów pracy urządzenia. Zgodnie z dokumentacją techniczno-konstrukcyjną symulatora HTC-07 [12] jego układ ruchu ma ograniczenia w zakresie wartości generowanych przyspieszeń względem poszczególnych osi: $K x_{K}= \pm 6 \mathrm{~g}, K y_{K}= \pm 10 \mathrm{~g}$, $K z_{K}=-3 /+16 \mathrm{~g}$ układu $K x_{K} y_{K} z_{K}$ związanego z kabiną (oznaczenie osi układu przedstawiono na rys. 7).

\section{Faza II - odtworzenie lotu rzeczywistego w symulatorze}

Właściwe odtworzenie lotu w wirówce przeciążeniowej HTC-07 poprzedzono sprawdzeniem procedury odtworzenia $\mathrm{w}$ symulatorze wektora $\mathbf{b}$ parametrów lotu rzeczywistego. $\mathrm{W}$ tym celu symulator uruchomiono w trybie offline, podczas którego układ ruchu pozostawał wyłączony. Pozytywne ukończenie tej procedury, potwierdzone poprawnym zobrazowaniem scenerii lotu oraz wskazań wysokości lotu, było warunkiem przeprowadzenia pełnego (z włączonym układem ruchu) odtworzenia lotu rzeczywistego. W przypadku niepowodzenia nastąpiło ponowne sprawdzenie formatu i zakresu wartości składowych wektora b oraz poprawności jego zapisu w pliku danych.

W wyniku odtworzenia lotu rzeczywistego (wektora b) w symulatorze HTC-07 utworzony został wektor k opisujący kinematykę kabiny symulatora. Spośród rejestrowanych przez symulator parametrów układu ruchu do utworzenia wektora $\mathbf{k}$ wybrano dane przedstawione w tabeli 5 .

Wektor $\mathbf{k}$ parametrów kinematyki kabiny symulatora HTC-07 (tabela 5) ma następującą postać w układzie współrzędnych $G x_{G} y_{G} z_{G}$ związanym z głową pilota

$$
\mathbf{k}=\left[\phi_{G / Z}^{h t c}, \theta_{G / Z}^{h t c}, \psi_{G / Z}^{h t c}, a_{x_{G}}^{h t c}, a_{y_{G}}^{h t c}, a_{z_{G}}^{h t c}, p_{K}^{h t c}, q_{K}^{h t c}, r_{K}^{h t c}\right]^{\mathrm{T}}
$$

Prędkość kątowa $\Omega_{K}^{h t c}=\left[p_{K}^{h t c}, q_{K}^{h t c}, r_{K}^{h t c}\right]^{\mathrm{T}}$ oddziałująca na głowę pilota w symulatorze jest sumą prędkości kątowej ramienia $r_{A}^{h t c}$, pierścienia $p_{P}^{h t c}$ oraz kabiny $q_{K}^{h t c}$ (tabela 5), przekształconych do układu $K x_{K} y_{K} z_{K}$ związanego z kabiną (układ zdefiniowany w Dodatku A, składowe tego wektora w układzie $K x_{K} y_{K} z_{K}$ opisane są zależnością (A.14)). 
Tabela 5. Wybrane parametry kinematyki kabiny symulatora HTC-07

\begin{tabular}{|c|c|c|c|c|c|}
\hline \multicolumn{2}{|c|}{ Parametr } & JM & $\begin{array}{c}\text { Układ } \\
\text { odniesienia }\end{array}$ & \begin{tabular}{|l} 
Skład. \\
wekt. k
\end{tabular} & Oznaczenie w pliku źródłowym \\
\hline \multirow{2}{*}{\multicolumn{2}{|c|}{$\begin{array}{l}\text { kąt przechylenia } \\
\text { pierścienia } \phi_{P}^{h t c} \\
\text { kąt pochylenia } \\
\text { kabiny } \theta_{K}^{h t c} \\
\end{array}$}} & \multirow{3}{*}{$\mathrm{rad}$} & \multirow{3}{*}{$\begin{array}{c}O_{Z} x_{Z} y_{Z} z_{Z} \\
\text { związany } \\
\text { z Ziemią }\end{array}$} & $\phi_{G / Z}^{h t c}$ & general.SysInput.DPLCout.Alpha.alpha \\
\hline & & & & $\theta_{G / Z}^{h t c}$ & general.SysInput.DPLCout.Beta.beta \\
\hline \multicolumn{2}{|c|}{$\begin{array}{l}\text { katt odchylenia } \\
\text { ramienia } \psi_{A}^{h t c}\end{array}$} & & & $\psi_{G / Z}^{h t c}$ & general.SysInput.DPLCout.Phi.phi \\
\hline \multirow{3}{*}{$\begin{array}{l}\text { przyspie- } \\
\text { szenie } \\
\text { liniowe }\end{array}$} & $a_{x_{K}}^{\text {htc }}$ & \multirow{3}{*}{$\mathrm{g}$} & \multirow{3}{*}{$\begin{array}{c}K x_{K} y_{K} z_{K} \\
\text { związany } \\
\text { z kabiną } \\
\end{array}$} & \multirow{3}{*}{$\mathbf{a}_{G}^{h t c}$} & general.SysInput.DPLCout.Indications.Gx \\
\hline & $a_{y_{K}}^{\text {htc }}$ & & & & general.SysInput.DPLCout.Indications.Gy \\
\hline & $a_{z_{K}}^{h t c}$ & & & & general.SysInput.DPLCout.Indications.Gz \\
\hline \multirow{3}{*}{$\begin{array}{l}\text { prędkość } \\
\text { kątowa }\end{array}$} & $\begin{array}{l}\text { pierś- } \\
\text { cienia } \\
p_{P}^{h t c}\end{array}$ & \multirow{3}{*}{$\mathrm{rad} / \mathrm{s}$} & $\begin{array}{c}K x_{P} y_{P} z_{P} \\
\text { związany z } \\
\text { pierścieniem* }\end{array}$ & \multirow{3}{*}{$\boldsymbol{\Omega}_{K}^{h t c^{* *}}$} & general.SysInput.DPLCout.Alpha.dalpha \\
\hline & $\begin{array}{l}\text { kabiny } \\
q_{K}^{h t c}\end{array}$ & & $\begin{array}{c}K x_{K} y_{K} z_{K} \\
\text { związany } \\
\text { z kabiną }\end{array}$ & & general.SysInput.DPLCout.Beta.dbeta \\
\hline & $\begin{array}{l}\text { ramie- } \\
\text { nia } r_{A}^{h t c}\end{array}$ & & $\begin{array}{c}K x_{A} y_{A} z_{A} \\
\text { związany } \\
\text { z ramieniem* }\end{array}$ & & general.SysInput.DPLCout.Phi.dphi \\
\hline
\end{tabular}

* - układ współrzędnych zdefiniowany w Dodatku A

** - wektor obliczony z wykorzystaniem przekształceń wyprowadzonych w Dodatku A

\section{Faza III - ocena odtworzonego lotu}

W celu określenia stopnia, z jakim odtwarzany w symulatorze HTC-07 profil lotu odzwierciedlił fragment kinematyki rzeczywistego lotu, porównano wybrane składowe wektora b, które reprezentują przyspieszenie liniowe $\left[a_{x_{G}}^{s}, a_{y_{G}}^{s}, a_{z_{G}}^{s}\right]$ i prędkość kątową $\left[p_{G}^{s}, q_{G}^{s}, r_{G}^{s}\right]$ z odpowiadającym im składowym wektora $\mathbf{k}$, tj. $\left[a_{x_{G}}^{h t c}, a_{y_{G}}^{h t c}, a_{z_{G}}^{h t c}\right]$ oraz $\left[p_{G}^{h t c}, q_{G}^{h t c}, r_{G}^{h t c}\right]$. Ponieważ porównywane składowe przyspieszenia liniowego nie zawierają komponentu przyspieszenia grawitacyjnego, w ocenie odtwarzanego profilu lotu uwzględniono również zgodność odwzorowania kątów orientacji przestrzennej (kątów $\phi_{S}, \theta_{S}, \psi_{S}$ ) opisujących orientację samolotu z kątami $\phi_{G / Z}^{\text {htc }}, \theta_{G / Z}^{\text {htc }}, \psi_{G / Z}^{\text {htc }}$, które określają orientację przestrzenną kabiny symulatora.

Do oceny odtworzonego lotu rzeczywistego w symulatorze HTC-07 zastosowano dwa wskaźniki:

a) pierwiastek błędu średniokwadratowego $(R M S E)$, który jest miarą dokładności służącą do agregowania odchyleń (wartości błędów między wybraną składową wektora b a odpowiadającym jej parametrem wektora k) w jedną miarę mocy zgodności. Im mniejsze odchylenia, tym mniejszy $R M S E$, a tym samym dokładniejsze odwzorowanie porównywanego parametru. RMSE obliczono za pomocą następującej zależności

$$
R_{M S E_{i}}=\sqrt{\frac{1}{N} \sum_{n=1}^{N}\left[b_{i}(n)-k_{i}(n)\right]^{2}}
$$

gdzie: $i$ - składowa wektora $\mathbf{b}$ oraz $\mathbf{k}, i=1,2,3, N$ - liczba próbek danych analizowanej składowej wektora, $b_{i}, k_{i}-i$-ta składowa wektora parametrów odpowiednio lotu rzeczywistego oraz kinematyki kabiny symulatora; 
b) współczynnik korelacji $r$, który opisuje siłę i kierunek zależności liniowej pomiędzy analizowanymi składowymi wektorów b i k. Współczynnik ten jest ilorazem kowariancji i iloczynu odchyleń standardowych tych składowych i obliczony został przy wykorzystaniu następującego równania

$$
r_{i}=\frac{\sum_{n=1}^{N}\left[b_{i}(n)-\bar{b}_{i}\right]\left[k_{i}(n)-\bar{k}_{i}\right]}{\sqrt{\sum_{n=1}^{N}\left[b_{i}(n)-\bar{b}_{i}\right]^{2}} \sqrt{\sum_{n=1}^{N}\left[k_{i}(n)-\bar{k}_{i}\right]^{2}}}
$$

gdzie: $\bar{b}_{i}, \bar{k}_{i}$ - wartość średnia $i$-tej składowej wektora.

Współczynnik korelacji osiąga wartości od -1 do 1 , przy czym im większa jego wartość bezwzględna, tym silniejsza jest zależność liniowa między porównywanymi składowymi.

\section{Wyniki}

Wszystkie obliczenia, w tym utworzenie wektorów $\mathbf{b}$ i $\mathbf{k}$ oraz pliku z danymi odtwarzanymi w symulatorze HTC-07, wykonano za pomocą oprogramowania MATLAB (MathWorks Inc., USA). Przeprowadzone testy potwierdziły poprawność struktury i formatu wektora b. Składowe tego wektora nie wykraczały poza zakres wartości dopuszczalnych dla symulatora.

W wyniku odtworzenia lotu rzeczywistego samolotu F-16 w symulatorze HTC-07 uzyskano przyspieszenia liniowe oraz prędkości kątowe kabiny, które razem z parametrami lotu rzeczywistego przedstawiono na rysunkach 4-6. Składowe wektora $\mathbf{b}=\left[\phi_{S}, \theta_{S}, \psi_{S}, a_{x_{G}}^{s}, a_{y_{G}}^{s}, a_{z_{G}}^{s}, p_{G}^{s}, q_{G}^{s}, r_{G}^{s}\right]^{\mathrm{T}}$ parametrów lotu rzeczywistego oznaczono linią ciągłą, natomiast składowe wektora $\mathbf{k}=\left[\phi_{G / Z}^{h t c}, \theta_{G / Z}^{h t c}, \psi_{G / Z}^{h t c}, a_{x_{G}}^{h t c}, a_{y_{G}}^{h t c}, a_{z_{G}}^{h t c}, p_{G}^{h t c}, q_{G}^{h t c}, r_{G}^{h t c}\right]^{\mathrm{T}}$, opisującego kinematyke kabiny symulatora podczas odtwarzania tego lotu, przedstawiono linią przerywaną.

\section{Wskaźniki zgodności odtworzenia lotu rzeczywistego}

W tabeli 6 przedstawiono wyniki porównania wybranych składowych wektora $\mathbf{k}$ z wektorem $\mathbf{b}$ w postaci wskaźników zgodności $R M S E$ oraz $r$, obliczonych przy wykorzystaniu odpowiednio równań (2.5) oraz (2.6). Omówienie tych wskaźników zamieszczono w dalszej części tego rozdziału przy opisie analizowanych parametrów.

Tabela 6. Wskaźniki zgodności porównywanych parametrów

\begin{tabular}{|l|c|c|c|}
\hline Parametr & $\begin{array}{c}\text { Składowe } \\
\text { wektora }\end{array}$ & $R M S E$ & $\begin{array}{c}\text { Współczynnik } \\
\text { korelacji } r\end{array}$ \\
\hline \hline \multirow{2}{*}{$\begin{array}{l}\text { Przyspieszenie } \\
\text { liniowe }\end{array}$} & $a_{x_{G}}$ & 1,97 & 0,53 \\
\cline { 2 - 4 } & $a_{y_{G}}$ & 0,83 & 0,14 \\
\cline { 2 - 4 } & $a_{z_{G}}$ & 6,10 & 0,91 \\
\hline \multirow{2}{*}{$\begin{array}{l}\text { Kąty określające } \\
\text { orientację } \\
\text { przestrzenną }\end{array}$} & $\phi_{G / Z}$ & 138,16 & $-0,49$ \\
\cline { 2 - 4 } & $\theta_{G / Z}$ & 18,82 & 0,16 \\
\cline { 2 - 4 } & $\psi_{G / Z}$ & 115,73 & 0,11 \\
\hline Prędkość kątowa & $p_{G}$ & 40,28 & 0,26 \\
\cline { 2 - 4 } & $q_{G}$ & 94,76 & 0,74 \\
\cline { 2 - 4 } & $r_{G}$ & 39,90 & 0,27 \\
\hline
\end{tabular}

\section{Przyspieszenie liniowe}

Na rys. 4 przedstawiono składowe wektora przyspieszenie liniowego oddziałujące na głowę pilota podczas rzeczywistego lotu samolotu F-16 (linia ciągła) oraz podczas odtwarzania tego 

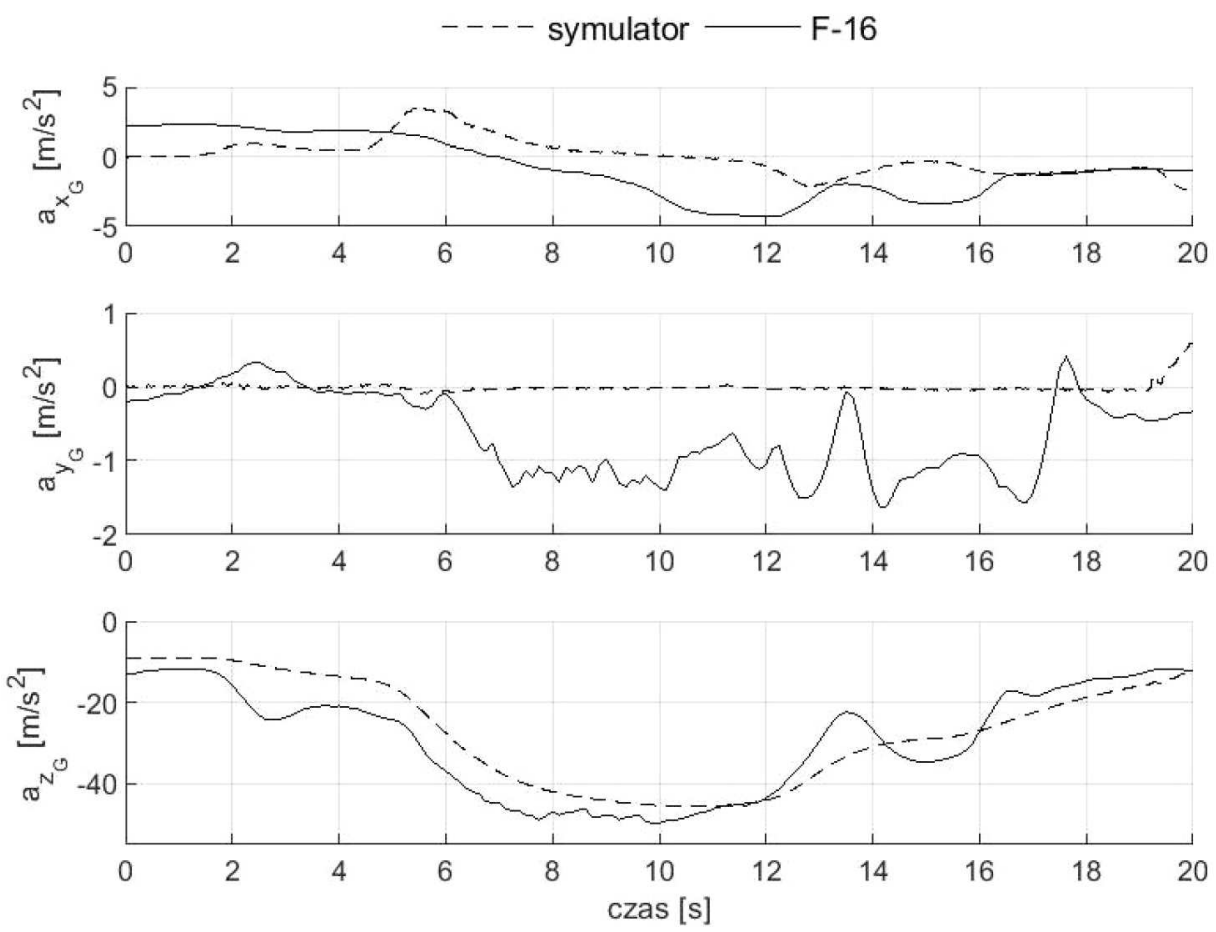

Rys. 4. Składowe wektora przyspieszenia liniowego zarejestrowane w locie rzeczywistym oraz podczas odtwarzania tego lotu w symulatorze (składowe opisane w układzie $G x_{G} y_{G} z_{G}$ związanym z głową pilota)

lotu w symulatorze HTC-07 (linia przerywana). Składowe te nie zawierają komponentu przyspieszenia grawitacyjnego.

W obu przypadkach w pierwszej fazie lotu (do 2 sekundy) przyspieszenia osiągały niewielkie wartości i były zbliżone przebiegiem. W dalszej części pojawia się wyraźna różnica w składowej $a_{z_{G}}$, która podobnie jak ma to miejsce podczas lotu samolotem, jest składową przyspieszenia liniowego dominująca w symulatorze. Przyczyną widocznej różnicy może być manewr zakrętu, który jak pokazano na rys. 6 , został wykonany z prędkością przechylania $p_{K}$ osiągającą $50^{\circ} / \mathrm{s}$. Zgodnie z przebiegiem przedstawionym na rys. 5 do 12 sekundy lotu zakręt ten utrzymywany był z katem przechylenia $\phi_{S}$ bliskim $90^{\circ}$. W tym czasie odtworzone w symulatorze przyspieszenie liniowe (linia przerywana) w porównaniu z przyspieszeniem zarejestrowanym w rzeczywistym locie (linia ciągła) wykazują największe niezgodności dla składowych $a_{x_{G}}$ oraz $a_{y_{G}}$.

$\mathrm{W}$ przypadku składowej $a_{x_{G}}$ widoczne różnice związane są z zastosowaną w algorytmie sterowania układem ruchu symulatora metodą kompensacji niepożądanego przyspieszenia stycznego. Przyspieszenie to pojawia się, gdy następuje zmiana prędkości obrotowej ramienia układu ruchu symulatora $\left(a_{x}=\epsilon_{A} d_{A}\right)$, a tym samym zmiany generowanego przyspieszenia $a_{z_{G}}$ (rys. 4 ). Kompensacja tego przyspieszenia stycznego polega na zmianie kąta pochylenia $\theta^{h t c}$ kabiny, co w rezultacie wpływa na występowanie chwilowych artefaktów w składowej pionowej $a_{z_{G}}$ generowanego przyspieszenia liniowego (rys. 4). Chociaż składowa $a_{z_{G}}$ uzyskała największy $R M S E$ (tabela 6 ), to obliczony współczynnik korelacji $r$ osiągnął najwyższą wartość $\left(r_{z_{G}}=0,91\right)$ spośród analizowanych przyspieszeń (tabela 6).

Ponadto na rys. 4 widać, że największe różnice w przebiegu odtwarzanego w symulatorze przyspieszenia ma składowa $a_{y_{G}}$ (linia przerywana). Zostało to potwierdzone najniższym współczynnikiem korelacji $r_{y_{G}}=0,14$. Należy jednak zwrócić uwagę, że różnice te osiągają w przybliżeniu jedynie $1 \mathrm{~m} / \mathrm{s}^{2}$ i są najmniejszymi w porównaniu do różnic obliczonych dla pozostałych składowych przyspieszenia liniowego $\left(R M S E_{a_{y}}=0,83\right.$; tabela 6$)$.

Pomimo że przebieg zmian składowych przyspieszenia liniowego generowanych w symulatorze znacznie różni się od przebiegu zarejestrowanego w locie rzeczywistym, to dla oceny zachowania 
się pilota w czasie lotu znaczenie mają wartości generowanych przez symulator przyspieszeń. Lambert [17], [18] zauważył, że zaburzenia wzrokowe podczas lotu pojawiają się przy wyższych wartościach przyspieszenia niż ma to miejsce podczas treningu w wirówkach przeciążeniowych. Różnica ta wynosi ok. 0,7 G i według autora jest zależna od różnicy stopnia napięcia emocjonalnego w obu sytuacjach oraz warunków lotu (aktywnego, podczas którego pilot kontroluje lot i związane z nim wartości generowanego przyspieszenia, vs. pasywny, gdy pilot nie ma wpływu na przebieg lotu i wytwarzane przyspieszenie).

\section{Kąty określające orientację przestrzenną}

Na rys. 5 pokazano, jak w czasie lotu zmieniały się kąty określające przestrzenną konfigurację samolotu (linia ciągła) oraz jak zmieniało się położenie kątowe kabiny symulatora podczas odtwarzania tego lotu (linia przerywana).
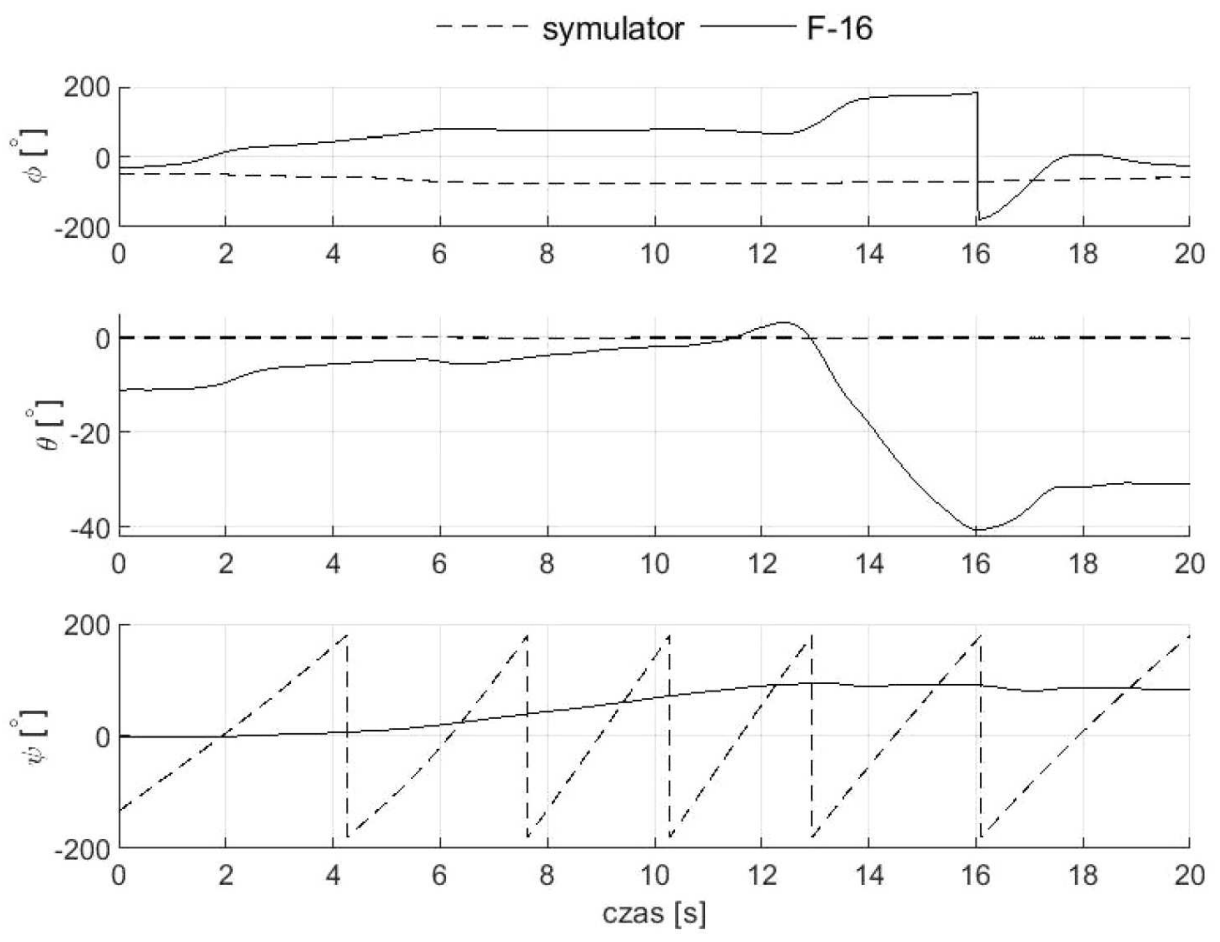

Rys. 5. Przestrzenna konfiguracja samolotu w locie rzeczywistym oraz kabiny podczas odtwarzania tego lotu w symulatorze (kąty opisują orientację względem układu $O_{Z} x_{Z} y_{Z} z_{Z}$ związanego z Ziemią)

Widać, że analizowany fragment lotu rozpoczął się wprowadzeniem w zakręt w prawo z jednoczesnym wyprowadzaniem z pochylenia na ujemnym kącie około $10^{\circ}$. Utrzymując zakręt z przechyleniem bliskim $90^{\circ}$, w około 13 sekundzie lotu nastąpiło pogłębienie przechylenia do pełnego obrotu, jednocześnie przechodząc gwałtownie na ujemny kąt pochylenia (osiągając $40^{\circ} \mathrm{w} 16$ sekundzie lotu).

Na każdym wykresie opisującym przestrzenną konfigurację samolotu (linia ciągła) i kabiny symulatora (linia przerywana) widoczne są różnice między rzeczywistym a odtworzonym w symulatorze położeniem kątowym pilota (rys. 5). Największe różnice uzyskano dla kąta przechylenia $\left(R M S E_{\phi_{G / Z}}=138,16\right)$, natomiast najmniejsze dla kąta pochylenia $\left(R M S E_{\theta_{G / Z}}=18,82\right)$. Niski poziom odtworzenia przestrzennej konfiguracji samolotu wykazał również współczynnik korelacji $r$ (tabela 6).

Widoczne niezgodności w odtwarzaniu przestrzennej konfiguracji samolotu mają wpływ na kierunek i zwrot wektora przyspieszenia ziemskiego, który razem z wektorem przyspieszenia 
liniowego (rys. 4) oddziałuje na głowę pilota zarówno w locie rzeczywistym, jak i w kabinie symulatora. Przyczyną niezgodności w odtwarzanych przez symulator kątach jest wykorzystanie przestrzennej konfiguracji kabiny symulatora do generowania określonych wartości składowych przyspieszenia liniowego. Widoczna na rys. 5 cykliczna zmiana kąta odchylenia $\psi_{G / Z}^{\text {htc }}$ (linia przerywana) związana jest $\mathrm{z}$ ruchem obrotowym ramienia symulatora podczas generowania tych przyspieszeń. Okazuje się zatem, że kąty opisujące przestrzenną orientację samolotu zostały zdefiniowane w minimalnym zestawie danych odtwarzanych w symulatorze HTC-07 (tabela 1) jedynie na potrzeby odwzorowania przestrzennego położenia samolotu $\mathrm{w}$ zobrazowanej scenerii lotu. Podobne przeznaczenie mają trzy inne składowe wektora b parametrów lotu rzeczywistego odtwarzanego w symulatorze HTC-07. Są to współrzędne geograficzne (długość i szerokość) oraz wysokość lotu (tabela 3).

\section{Prędkość kątowa}

Na rys. 6 przedstawiono składowe wektora prędkości kątowej oddziałującej na głowę pilota w locie rzeczywistym (linia ciągła) oraz wektora tej prędkości podczas odtwarzania tego lotu w symulatorze (linia przerywana).
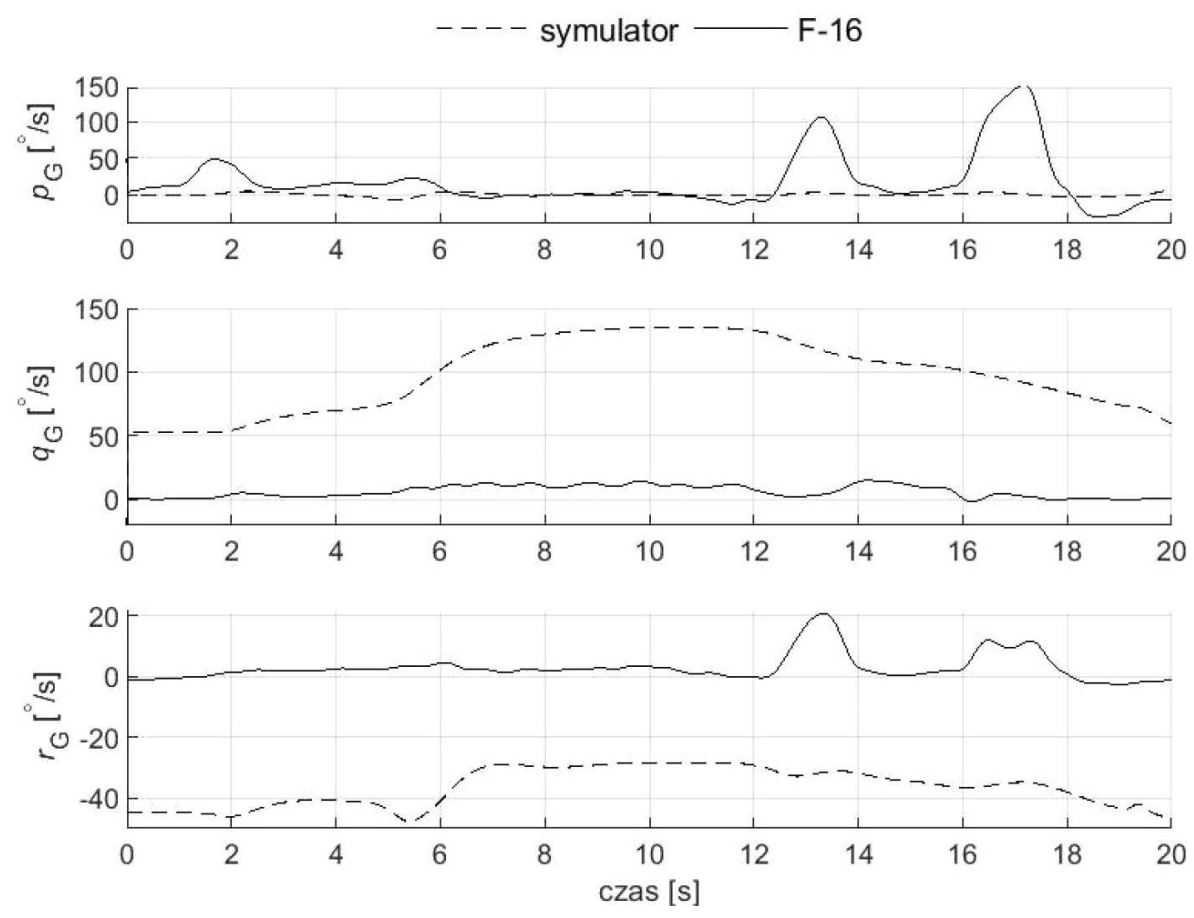

Rys. 6. Składowe wektora prędkości kątowej zarejestrowane w locie rzeczywistym oraz podczas odtwarzania tego lotu w symulatorze (prędkości opisane w układzie $G x_{G} y_{G} z_{G}$ związanym z głową pilota)

Porównując pokazane na rys. 6 przebiegi składowych prędkości kątowej odtwarzanej w symulatorze z zapisem rejestratora, widać, że najbliższe mu są wyniki otrzymane dla prędkości przechylania $p_{G}$. Uwzględniając $\mathrm{w}$ tej ocenie wskaźniki zgodności obliczone dla tej składowej prędkości kątowej, można zauważyć, że zarówno $R M S E_{p}$, jak i współczynnik $r_{p}$ (tabela 6) nie potwierdzają powyższego spostrzeżenia.

Inna sytuacja występuje w przypadku dwóch pozostałych prędkości pochylania $q_{G}$ i odchylania $r_{G}$ (rys. 6, linia przerywana). Są to dwie składowe prędkości kątowej, które nieprzerwalnie oddziałują na głowę pilota. Ich występowania związane jest z ruchem obrotowym ramienia symulatora oraz występującym przechyleniu kabiny, które sprowadza generowane przyspieszenie dośrodkowe oraz przyspieszenie grawitacyjne do przyspieszenia wypadkowego oddziałującego 
na pilota (przykładowo dla generowanego w symulatorze przyspieszenia $+2 G_{z}$ kąt przechylania kabiny wynosi $\left.\phi^{h t c}=58^{\circ}\right)$. Chociaż z tych dwóch składowych prędkość pochylania $q_{G}$ wykazuje najmniejszą zgodność z prędkością zarejestrowaną w locie rzeczywistym $\left(R M S E_{q}=94,76\right.$; tabela 6), to przebieg jej zmian jest najbardziej zbliżony do przebiegu prędkości odtwarzanej w symulatorze $\left(r_{q}=0,74\right.$; tabela 6$)$.

Widoczne różnice składowych prędkości kątowej (rys. 6, tabela 6) odtworzonych w wirówce przeciążeniowej HTC-07 wynikają z faktu, że symulator ten do odtworzenia lotu nie wymaga wprowadzenia prędkości kątowej zarejestrowanej w locie rzeczywistym (tabela 2). Wytwarzaną przez symulator prędkość kątową można zatem określić produktem ubocznym procedury generowania przez układ ruchu symulatora przyspieszenia liniowego. Uwzględniając jednak fizjologię działania narządu przedsionkowego człowieka, który jest sensorem odpowiedzialnym m.in. za wykrywanie prędkości kątowej, widoczne na rys. 6 różnice między prędkościami kątowymi w locie rzeczywistym a prędkościami podczas odtwarzania tego lotu w symulatorze, mogą nie mieć istotnego znaczenia dla pilota. W obecności bodźca w postaci stałej prędkości kątowej narząd przedsionkowy daje mylne odczucie zanikania ruchu obrotowego [19]. Dlatego też przy stałej prędkości kątowej ruchu ramienia i niezmiennym położeniu kątowym kabiny oraz głowy nie powinno wystąpić u pilota odczucie ruchu obrotowego. Jedynie wraz z nagłym wzrostem lub spadkiem wytwarzanego przez symulator przyspieszenia liniowego (rys. 6, 6 oraz 12 sekunda) zmianie ulega prędkość kątowa ramienia i kąt przechylania kabiny (rys. 5). W takiej sytuacji pilot może odczuć ruch obrotowy, którego nie dostrzegłby w locie rzeczywistym.

\subsection{Ograniczenia w wykorzystaniu wirówki przeciążeniowej}

W przedstawionym badaniu wykryto kilka problemów wskazujących na to, że symulator lotu oparty na wirówce ma ograniczone możliwości wykorzystania w scenariuszach odtworzenia lotu rzeczywistego. W szczególności istnieje zasadnicza różnica między lotem rzeczywistym z sześcioma stopniami swobody, a środowiskiem o trzech stopniach, jakie zapewnia wirówka. Pomimo że głównym zadaniem tego symulatora jest generowanie przyspieszeń liniowych występujących podczas lotu rzeczywistego, to nie został on zoptymalizowany pod katem ich dokładnego odwzorowania. Ograniczenie to dotyczy przede wszystkim sposobu odtwarzania warunków lotu z przyspieszeniem poniżej $+1,4 G_{z}$.

Inną niedoskonałością wirówki przeciążeniowej są artefakty w postaci bodźców ruchowych, które nie występują w odtwarzanym locie rzeczywistym. Przyjęte w pracy założenie, że podczas odtwarzania lotu w wirówce pilot nie wykonuje ruchów głową, miało na celu wyeliminowanie przynajmniej jednej z grupy tych bodźców. Jest to oczywiście założenie upraszczające, gdyż w rzeczywistości podczas lotu, a zwłaszcza walki powietrznej, ruchy głowy są zjawiskiem naturalnym i pożądanym. W przypadku lotu odtwarzanego w wirówce przeciążeniowej ruch głowy podczas obrotu ramienia głównego symulatora pobudza jednocześnie wszystkie kanały półkoliste narządu przedsionkowego, w rezultacie wyzwalając u pilota nieprzyjemne doznania ruchowe. Ze względu na swój charakter doznania te są silnym bodźcem stymulującym do występowania choroby lokomocyjnej (w środowisku symulatora zwanej chorobą symulatorową).

\section{Wnioski}

Zastosowanie dynamicznego symulatora lotu - wirówki przeciążeniowej do odtworzenia warunków, w których miał miejsce faktyczny wypadek, wydaje się być unikalnym sposobem wsparcia dochodzenia $\mathrm{w}$ sprawie wypadku lotniczego. Przedstawione $\mathrm{w}$ pracy wyniki odtworzenia w symulatorze HTC-07 fragmentu lotu samolotu F-16 bazowały na zapisie rejestratora katastroficznego ECSMU. 
Chociaż żadna ze składowych przyspieszenia liniowego nie została odwzorowana na bardzo wysokim poziomie zgodności, to najbliższy wynikom rejestracji z lotu rzeczywistego jest składowa $a_{z_{G}}$ (rys. 4). W przypadku pozostałych parametrów (kątów określających przestrzenną orientację oraz prędkości kątowych) symulator HTC-07 wykazał niską bądź bardzo niską zgodność odwzorowania. Nie jest on zatem symulatorem, który wiernie odtwarza lot rzeczywisty samolotu i choć umożliwia odwzorowanie przyspieszeń liniowych na wysokim poziomie zgodności, to za sprawą generowania dodatkowych bodźców ruchowych (m.in. prędkości pochylania i odchylania) może wywoływać u pilota odczucia, które nie są spotykane w locie rzeczywistym. Biorąc jednakże pod uwagę to, że zaburzenia wzrokowe oraz utrata świadomości u pilota są wynikiem głównie składowej pionowej $a_{z_{G}}$ przyspieszenia liniowego, to niedostateczna zgodność w odtwarzaniu pozostałych składowych tego przyspieszenia oraz składowych prędkości kątowej nie dyskwalifikuje tego symulatora z możliwości jego zastosowania w badaniach przyczyn wypadków lotniczych.

Z punktu widzenia mechaniki lotu i wpływu prędkości kątowych samolotu na zdolność pilota do zachowania prawidłowej orientacji przestrzennej poza przyspieszeniem liniowym pożądana jest również wysoka zgodność odtwarzanych w symulatorze prędkości kątowych. Poprawne ich odwzorowanie umożliwiłoby zwiększenie zakresu badań o błędy percepcyjne pilota, które mogły być przyczyną utraty orientacji przestrzennej w locie.

W czasie badań przyczyn wypadku lotniczego z wykorzystaniem dynamicznego symulatora lotu HTC-07 moga pojawić się trudności z oceną wpływu przyspieszeń na pilota w czasie krytycznej fazy lotu. Trudności te mogą wynikać przede wszystkim z braku informacji na temat prawidłowego wykonania AGSM. Zbyt późne rozpoczęcie AGSM, słabe napięcie mięśni dolnej części ciała lub niewłaściwy cykl oddychania obniżają tolerancje przyspieszeń i predysponują do wystąpienia G-LOC u pilota.

Dzięki możliwości odtwarzania w symulatorze HTC-07 scenariuszy lotu rzeczywistego, możliwe jest przeprowadzanie badań w bezpiecznych, kontrolowanych i powtarzalnych warunkach. Ponadto, bazując na danych i wnioskach z zaistniałych poważnych incydentów i wypadków lotniczych, taka funkcjonalność symulatora może również zapewnić środowisko do szkolenia pilotów.

Przedstawiona w artykule procedura odtworzenia rzeczywistego lotu w symulatorze HTC-07 może być zastosowana w symulatorach lotu, których konstrukcja oparta została na wirówce przeciążeniowej. Urządzenia o podobnej konstrukcji i systemie sterowania układem ruchu znajdują się w użytkowaniu m.in. Indyjskich Siły Powietrznych, Sił Powietrznych Republiki Singapuru, Niemieckich Sił Powietrznych oraz Sił Powietrznych Wielkiej Brytanii. Należy jednak zaznaczyć, że choć symulacja lotu okazuje się wartościowym narzędziem w badaniach przyczyn wypadków lotniczych, to ograniczenia tych urządzeń i pozornie wysoki poziom ich wierności w zakresie odwzorowania środowiska lotu mogą skłonić nieświadomego badacza do wyciągnięcia błędnych wniosków.

\section{Dodatek A - Wyznaczenie składowych prędkości kątowej oddziałującvch na głowę pilota w kabinie symulatora}

\section{Układy wspótrzędnych i ich transformacje}

Do opisu położenia i prędkości kątowej komponentów układu ruchu symulatora (ramienia, pierścienia i kabiny), przyjęto cztery prostokątne układy współrzędnych (rys. 7):

- nieruchomy układ współrzędnych związany z Ziemią $-O_{Z} x_{Z} y_{Z} z_{Z}$, o początku leżącym na powierzchni Ziemi, w osi obrotu ramienia symulatora;

- układ współrzędnych związany z ramieniem symulatora - Kx $x_{A} y_{A} z_{A}$, którego początek przyjmuje się w punkcie $K$ przecięcia osi obrotu pierścienia i kabiny symulatora. Wartości wyrażane w tym układzie oznaczono indeksem dolnym $A$; 
- układ współrzędnych związany z pierścieniem - K $x_{P} y_{P} z_{P}$, którego początek w punkcie $K$ pokrywa się z początkiem układu $K x_{A} y_{A} z_{A}$. Oś $K x_{P}$ pokrywa się z osią $K x_{A}$ układu związanego z ramieniem, natomiast oś $K y_{P}$ jest osią obrotu kabiny. Wartości wyrażane w układzie związanym z pierścieniem wyróżniono indeksem dolnym $P$;

- układ współrzędnych związany z kabiną - $K x_{K} y_{K} z_{K}$, o początku w punkcie $K$, pokrywającym się z początkiem układu $K x_{A} y_{A} z_{A}$. Oś $K y_{K}$ jest osią obrotu kabiny i pokrywa się z osią $K y_{P}$ układu związanego z pierścieniem. Wartości wyrażane w tym układzie oznaczono indeksem dolnym $K$.

Kierunki i zwroty poszczególnych osi układów współrzędnych pokazano na rys. 7.

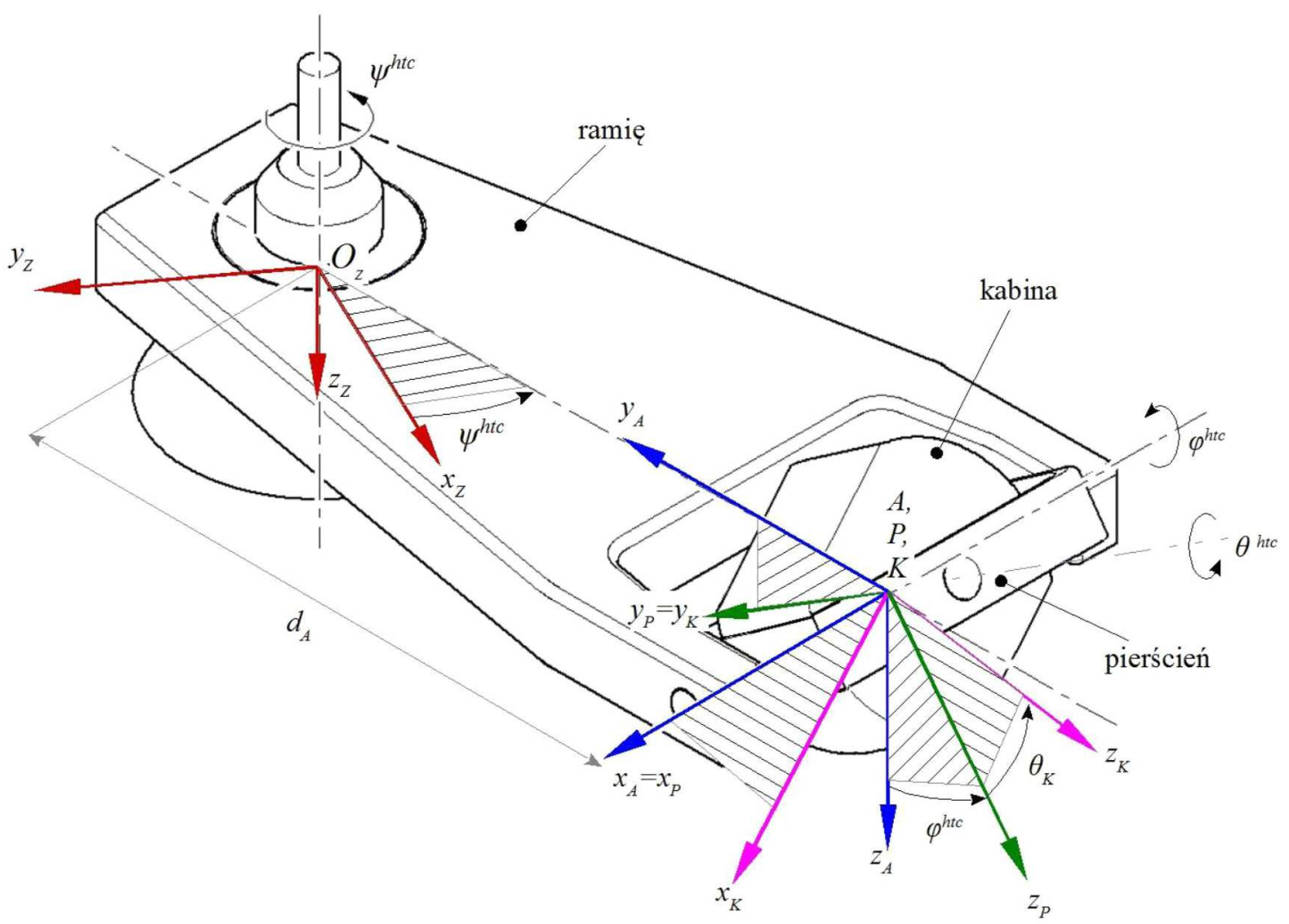

Rys. 7. Układy współrzędnych symulatora HTC-07 oraz kąty przejścia pomiędzy nimi

Zainstalowany we wnętrzu kabiny symulatora fotel pilota przy kącie pochylenia oparcia $\theta_{G}$ wynoszącym $0^{\circ}$ zapewnia pokrycie początku układu współrzędnych $G x_{G} y_{G} z_{G}$ związanego z głową z początkiem układu $K x_{K} y_{K} z_{K}$ związanego z kabiną. Odtwarzając w symulatorze HTC-07 warunki lotu samolotem F-16, wymagane jest ustawienie oparcia fotela w kącie pochylenia do tyłu odpowiednio o kąt $\theta_{G}=30^{\circ}$. Przy takiej konfiguracji fotela występuje przesunięcie początku układu $G x_{G} y_{G} z_{G}$ względem początku układu $K x_{K} y_{K} z_{K}$. Konstrukcja fotela zapewnia możliwość zmiany jego położenia w zakresie przód-tył oraz góra-dół, zapewniając wyeliminowanie tego przesunięcia, co też w badaniach zostało uwzględnione.

\section{Wzajemne położenie i macierze przejść między uktadami wspótrzędnych}

Do określenia wzajemnego położenia zdefiniowanych w symulatorze lotu układów współrzędnych, wykorzystano następujące kąty:

- $\psi^{h t c}$ - kąt odchylenia (rys. 7) zawarty między osią $O_{Z} x_{Z}$ a osią $K y_{A}$. Kąt ten powiększony o kąt $90^{\circ}$ zapewnia pokrycie osi $O_{Z} y_{Z}$ z osią $K y_{A}$, definiując położenie układu $O_{Z} x_{Z} y_{Z} z_{Z}$ związanego z Ziemią względem układu $K x_{A} y_{A} z_{A}$ związanego z ramieniem, 
- $\phi^{\text {htc }}$ - kąt przechylenia (rys. 7), zawarty między osią $K z_{A}$ a osią $K z_{P}$ określa położenie układu $K x_{A} y_{A} z_{A}$ związanego z ramieniem względem układu $K x_{P} y_{P} z_{P}$ związanego z pierścieniem,

- $\theta^{\text {htc }}$ - kąt pochylenia (rys. 7), zawarty między osią $K z_{P}$ a osią $K z_{K}$ określa położenie układu $K x_{P} y_{P} z_{P}$ związanego z pierścieniem względem układu $K x_{K} y_{K} z_{K}$ związanego z kabiną.

Na podstawie przyjętej konwencji obrotów układów współrzędnych (kolejno względem osi $Z \rightarrow$ $Y \rightarrow X)$ otrzymano następujące macierze przejść pomiędzy nimi:

- macierz przejścia $\mathbf{L}_{A / Z}$ z układu $O_{Z} x_{Z} y_{Z} z_{Z}$ związanego z Ziemią do układu $K x_{A} y_{A} z_{A}$ związanego z ramieniem otrzymuje się, dokonując obrotów kolejno o kąt $\psi^{h t c}$ oraz kąt $90^{\circ}$, uzyskując następujący związek

$$
\left[\begin{array}{l}
x_{A} \\
y_{A} \\
z_{A}
\end{array}\right]=\mathbf{L}_{A / Z}\left[\begin{array}{c}
x_{Z} \\
y_{Z} \\
z_{Z}
\end{array}\right]=\mathbf{L}_{z_{A}}\left(\frac{\pi}{2}\right) \mathbf{L}_{z_{Z}}\left(-\psi^{h t c}\right)\left[\begin{array}{c}
x_{Z} \\
y_{Z} \\
z_{Z}
\end{array}\right]
$$

dla którego macierze transformacji są następujące

$$
\begin{aligned}
& \mathbf{L}_{z_{Z}}\left(-\psi^{h t c}\right)=\left[\begin{array}{ccc}
\cos \psi^{h t c} & -\sin \psi^{h t c} & 0 \\
\sin \psi^{h t c} & \cos \psi^{h t c} & 0 \\
0 & 0 & 1
\end{array}\right] \quad \mathbf{L}_{z_{A}}\left(\frac{\pi}{2}\right)=\left[\begin{array}{ccc}
\cos \frac{\pi}{2} & -\sin \frac{\pi}{2} & 0 \\
\sin \frac{\pi}{2} & \cos \frac{\pi}{2} & 0 \\
0 & 0 & 1
\end{array}\right] \\
& \mathbf{L}_{A / Z}=\left[\begin{array}{ccc}
-\sin \psi^{h t c} & -\cos \psi^{h t c} & 0 \\
\cos \psi^{h t c} & \sin \psi^{h t c} & 0 \\
0 & 0 & 1
\end{array}\right]
\end{aligned}
$$

- macierz przejścia $\mathbf{L}_{P / A}$ z układu $K x_{A} y_{A} z_{A}$ związanego z ramieniem do układu $K x_{P} y_{P} z_{P}$ związanego z pierścieniem opisuje rownanie

$$
\left[\begin{array}{l}
x_{P} \\
y_{P} \\
z_{P}
\end{array}\right]=\mathbf{L}_{P / A}\left[\begin{array}{l}
x_{A} \\
y_{A} \\
z_{A}
\end{array}\right]
$$

gdzie

$$
\mathbf{L}_{P / A}=\left[\begin{array}{ccc}
1 & 0 & 0 \\
0 & \cos \phi^{h t c} & \sin \phi^{h t c} \\
0 & -\sin \phi^{h t c} & \cos \phi^{h t c}
\end{array}\right]
$$

- macierz przejścia $\mathbf{L}_{K / P} \mathrm{z}$ układu $K x_{P} y_{P} z_{P}$ związanego z pierścieniem do układu $K x_{K} y_{K} z_{K}$ związanego z kabiną opisuje związek

$$
\left[\begin{array}{l}
x_{K} \\
y_{K} \\
z_{K}
\end{array}\right]=\mathbf{L}_{K / P}\left[\begin{array}{l}
x_{P} \\
y_{P} \\
z_{P}
\end{array}\right]
$$

gdzie

$$
\mathbf{L}_{K / P}=\left[\begin{array}{ccc}
\cos \theta^{h t c} & 0 & -\sin \theta^{h t c} \\
0 & 1 & 0 \\
\sin \theta^{h t c} & 0 & \cos \theta^{h t c}
\end{array}\right]
$$


Przejście z układu $O_{Z} x_{Z} y_{Z} z_{Z}$ związanego z Ziemią do układu $K x_{K} y_{K} z_{K}$ związanego z kabiną odbywa się przez kolejne przekształcenia za pomocą macierzy: $\mathbf{L}_{A / Z}(\mathrm{~A} .2)_{3}, \mathbf{L}_{P / A}$ (A.4) oraz $\mathbf{L}_{K / P}$ (A.6). Przekształcenie to opisuje równanie

$$
\left[\begin{array}{l}
x_{K} \\
y_{K} \\
z_{K}
\end{array}\right]=\mathbf{L}_{K / Z}\left[\begin{array}{l}
x_{Z} \\
y_{Z} \\
z_{Z}
\end{array}\right]
$$

w którym $\mathbf{L}_{K / Z}$ jest macierzą przejścia wyznaczaną z iloczynu

$$
\mathbf{L}_{K / Z}=\mathbf{L}_{K / P} \mathbf{L}_{P / A} \mathbf{L}_{z_{Z}}\left(\frac{\pi}{2}\right) \mathbf{L}_{z_{Z}}\left(-\psi^{h t c}\right)
$$

a jej elementy są następujące

$$
\begin{aligned}
& \left(\mathbf{L}_{K / Z}\right)_{11}=\cos \psi^{h t c} \sin \theta^{h t c} \sin \phi^{h t c}-\sin \psi^{h t c} \cos \theta^{h t c} \\
& \left(\mathbf{L}_{K / Z}\right)_{12}=-\cos \psi^{h t c} \cos \theta^{h t c}-\sin \psi^{h t c} \sin \phi^{h t c} \sin \theta^{h t c} \\
& \left(\mathbf{L}_{K / Z}\right)_{13}=-\cos \phi^{h t c} \sin \theta^{h t c} \\
& \left(\mathbf{L}_{K / Z}\right)_{21}=\cos \psi^{h t c} \cos \phi^{h t c} \\
& \left(\mathbf{L}_{K / Z}\right)_{22}=-\sin \psi^{h t c} \cos \phi^{h t c} \\
& \left(\mathbf{L}_{K / Z}\right)_{23}=\sin \phi^{h t c} \\
& \left(\mathbf{L}_{K / Z}\right)_{31}=-\sin \psi^{h t c} \sin \theta^{h t c}+\cos \psi^{h t c} \sin \phi^{h t c} \cos \theta^{h t c} \\
& \left(\mathbf{L}_{K / Z}\right)_{32}=\sin \psi^{h t c} \sin \phi^{h t c} \cos \theta^{h t c}-\cos \psi^{h t c} \sin \theta^{h t c} \\
& \left(\mathbf{L}_{K / Z}\right)_{33}=\cos \phi^{h t c} \cos \theta^{h t c}
\end{aligned}
$$

Zakładając brak zmiany kąta odchylenia ramienia symulatora $\psi^{\text {htc }}=0$, macierz $\mathbf{L}_{K / Z}$ można uprościć do postaci

$$
\mathbf{L}_{K / Z}=\left[\begin{array}{ccc}
\sin \phi^{h t c} \sin \theta^{h t c} & -\cos \theta^{h t c} & -\cos \phi^{h t c} \sin \theta^{h t c} \\
\cos \phi^{h t c} & 0 & \sin \phi^{h t c} \\
\sin \phi^{h t c} \cos \theta^{h t c} & -\sin \theta^{h t c} & \cos \phi^{h t c} \cos \theta^{h t c}
\end{array}\right]
$$

\section{Prędkość kątowa oddziatująca na głowę pilota w kabinie symulatora}

Przyjmując, że w czasie lotu nie występuje ruch liniowy i kątowy głowy pilota względem kabiny, otrzymujemy równość: $\boldsymbol{\Omega}_{G}=\boldsymbol{\Omega}_{K}$. Wówczas prędkość kątowa $\boldsymbol{\Omega}_{K}$ oddziałująca na głowę pilota jest sumą prędkości kątowej ramienia $\dot{\psi}^{h t c}$, pierścienia $\dot{\phi}^{h t c}$ oraz kabiny $\dot{\theta}^{h t c}$ przekształconych do układu $K x_{K} y_{K} z_{K}$ związanego z kabiną. Prędkość ta w układzie $K x_{K} y_{K} z_{K}$ opisana jest zależnością

$$
\boldsymbol{\Omega}_{K}=\left[\begin{array}{c}
p_{K} \\
q_{K} \\
r_{K}
\end{array}\right]=\mathbf{L}_{K / Z} \dot{\psi}^{h t c}+\mathbf{L}_{K / P} \dot{\phi}^{h t c}+\dot{\theta}^{h t c}
$$

która sprowadzona do postaci

$$
\left[\begin{array}{c}
p_{K} \\
q_{K} \\
r_{K}
\end{array}\right]=\mathbf{L}_{K / Z}\left[\begin{array}{c}
0 \\
0 \\
\dot{\psi} h t c
\end{array}\right]+\mathbf{L}_{K / P}\left[\begin{array}{c}
\dot{\phi}^{h t c} \\
0 \\
0
\end{array}\right]+\left[\begin{array}{c}
0 \\
\dot{\theta}^{h t c} \\
0
\end{array}\right]
$$


oraz po wyznaczeniu iloczynu

$$
\left[\begin{array}{c}
p_{K} \\
q_{K} \\
r_{K}
\end{array}\right]=\left[\begin{array}{c}
-\dot{\psi}^{h t c} \cos \phi^{h t c} \sin \theta^{h t c} \\
\dot{\psi}^{h t c} \sin \phi^{h t c} \\
\dot{\psi}^{h t c} \cos \phi^{h t c} \cos \theta^{h t c}
\end{array}\right]+\left[\begin{array}{c}
\dot{\phi}^{h t c} \cos \theta^{h t c} \\
0 \\
\dot{\phi}^{h t c} \sin \theta^{h t c}
\end{array}\right]+\left[\begin{array}{c}
0 \\
\dot{\theta}^{h t c} \\
0
\end{array}\right]
$$

przyjmuje postać

$$
\left[\begin{array}{c}
p_{K} \\
q_{K} \\
r_{K}
\end{array}\right]=\left[\begin{array}{c}
\dot{\phi}^{h t c} \cos \theta^{h t c}-\dot{\psi}^{h t c} \cos \phi^{h t c} \sin \theta^{h t c} \\
\dot{\theta}^{h t c}+\dot{\psi}^{h t c} \sin \phi^{h t c} \\
\dot{\phi}^{h t c} \sin \theta^{h t c}+\dot{\psi}^{h t c} \cos \phi^{h t c} \cos \theta^{h t c}
\end{array}\right]
$$

\section{Bibliografia}

1. Tydeman R., The Use of Full Flight Simulators for Accident Investigation, London, UK, 2004

2. Tran D., Hernandez E., Use of the vertical motion simulator in support of the American airlines flight 587 accident investigation, AIAA Modeling and Simulation Technologies Conference and Exhibit, AIAA Inc., Rhode Island, 1-7, 2004

3. WojtKowiak M., Badanie tolerancji ustroju na działanie przyspieszeń na podstawie oceny prędkości przeplywu krwi w tętnicy skroniowej i zaburzeń wzrokowych, Wojskowy Instytut Medycyny Lotniczej, Warszawa, 1982

4. Wood E.H., G-Induced Loss of Consciousness and Its Prevention, USAFSAM-TR-87-41, Brooks Air Force Base, TX, 1988

5. Truszczyński O., Wojtkowiak M., Lewkowicz R., Biernacki M.P., Kowalczuk K., Reaction time in pilots at sustained acceleration of $+4.5 \mathrm{Gz}$, Aviation, Space, and Environmental Medicine, 84, 8, 845-849, 2013

6. Truszczyński O., Lewkowicz R., Wojtkowiak M., Biernacki M.P., Reaction time in pilots during intervals of high sustained G, Aviation, Space, and Environmental Medicine, 85, 11, 11141120,2014

7. Balldin U.I., Derefeldt G., Eriksson L., Werchan P.M., Andersson P., Yates J.T., Color vision with rapid-onset acceleration, Aviation, Space, and Environmental Medicine, 74, 1, 29-36, 2003

8. Randjelović D., Pavlović M., The effect of acceleration on color vision, Vojnosanitetski Pregled, 75, 6, 623-627, 2018

9. White W.J., 1960, Variations In Absolute Visual Thresholds During Acceleration Stress, ASDTR-60-34, DTIC No. AD0243612, Wright-Patterson Air Force Base, OH, 1960

10. Comrey A.L., Canfield A.A., Wilson R.C., Zimmerman W.S., The effect of increased positive radial acceleration upon perceptual speed ability, Journal of Aviation Medicine, 22, 1, 60-64, 1951

11. Truszczyński O., Wojtkowiak M., Biernacki M.P., Kowalczuk K., Lewkowicz R., 2012, Effect of high acceleration exposure on visual perception in Polish pilots measured with Critical Fusion Frequency Test (CFFT), Polish Journal of Aviation Medicine and Psychology, 1, 1, 19-27, 2012

12. Amst-Systemtechnik GmbH, 2011, User manual Human Training Centrifuge HTC-0\%, AmstSystemtechnik GmbH, Austria

13. Truszczý́ski O., Kowalczuk K., The polish centrifuge as a dynamic flight simulator. New application and ideas, Polish Journal of Aviation Medicine and Psychology, 18, 3, 71-80, 2012 
14. Szelmanowski A., Jakielaszek Z., Błędy skrośne w pomiarach parametrów ruchu statku powietrznego i możliwości ich korekcji, Pomiary Automatyka Kontrola, 53, 9, 564-567, 2007

15. Szelmanowski A., Metoda korekcji błędów skrośnych dla pomiarów parametrów ruchu w zintegrowanych systemach awionicznych, Research Works of Air Force Institute of Technology, 25, 1, 209-223, 2009

16. Della Santina C.C., Potyagaylo V., Migliaccio A.A., Minor L.B., Carey J.P., Orientation of human semicircular canals measured by three-dimensional multiplanar CT reconstruction, Journal of the Association for Research in Otolaryngology, 6, 3, 191-206, 2005

17. Lambert E.H., Comparison of the physiologic effect of positive acceleration on a human centrifuge and in an airplane, Journal of Aviation Medicine, 20, 5, 308-335, 1949

18. LAMBERT E.H., Effects of positive acceleration on pilots in flight with a comparison, Journal of Aviation Medicine, 21, 3, 195-220, 1950

19. Lewkowicz R., Kowaleczko G., Ocena jakości odwzorowania przyspieszeń w wirówce przeciążeniowej, [W:] Mechanika w Lotnictwie, ML-XVIII 2018, K. Sibilski (Red.), ZG PTMTS, Warszawa, s. $67-78,2018$

\section{The use of a dynamic flight simulator for aviation mishap investigation}

The study was aimed to assess the usefulness of a dynamic flight simulator - human training centrifuge HTC-07 to reproduce a flight of F-16 aircraft during a critical phase. The assessment was based on comparison of linear acceleration and angular velocity acting on the pilot in a real flight with the acceleration during reconstruction of that flight in the simulator. For the assessment, the root-meansquare error and linear correlation coefficients were used. Considering that visual disturbances and loss of consciousness of pilots result mainly due to the vertical component of linear acceleration, insufficient compliance in the reconstruction of other components of the acceleration and angular velocity does not disqualify this simulator from being used for aircraft accidents and investigation of incidents. 